\title{
BAHASA INDONESIA, DAERAH, DAN ASING DI WILAYAH PERBATASAN: STUDI PADA BAHASA WAISA DAN MUYU
}

\section{BAHASA INDONESIA, LOCAL LANGUAGES, AND FOREIGN LANGUAGE IN BORDER AREA: STUDY ON THE WAISA AND MUYU LANGUAGES}

\author{
Buha Aritonang \\ Badan Pengembangan dan Pembinaan Bahasa \\ Jalan Daksinapati Barat IV, Rawamangun, Jakarta 13220 \\ e-mail: buhaaritonang@yahoo.co.id
}

Naskah diterima tanggal: 25-9-2017, disetujui tanggal: 10-11-2017

\begin{abstract}
People's perception in border area toward bahasa Indonesia, local and foreign language is still relevant to be observed. In this regard, the study purpose is to describe the characteristics of Banda and Kombut respondents who live in the border areas of Indonesia and Papua New Guinea and their perceptions toward bahasa Indonesia (language of Indonesian people), local languages (Walsa and Muyu), and foreign language (Papua New Guinea language) which related to the policy on Indonesian and local assistance. To reach that goal, this research model is using quantitative model with descriptive method. This research is classified as field research with primary and secondary data types. The sample consists of 108 respondents of Kampung Banda and 110 of Kampung Kombut. The data were processed by simple tabulation analysis and Likert scale with reference to the average score formula. The results of this research indicate that Banda people's perception is very positive towards bahasa Indonesia, positive to Walsa language, and not positive to Papua New Guinea language. Kombut people's perception is positive towards bahasa Indonesia, quite positive both towards Muyu and of Papua New Guinea language. The perceptions of those two communities toward bahasa Indonesia, and their local languages due to loyalty, proudness, and awareness of bahasa Indonesia, Walsa, and Muyu norms. The results of people's perception toward Papua New Guinea language which are Banda is not positive and Kombut is quite positive as they do not use the language as a medium of daily communication.
\end{abstract}

Keywords: bahasa Indonesia, people's perception, border area, foreign language

\begin{abstract}
Abstrak: Masyarakat tutur wilayah perbatasan terhadap bahasa Indonesia, daerah, dan asing masih relevan untuk dicermati. Sehubungan dengah hal itu, penelitian ini bertujuan untuk mendeskripsikan karakteristik responden masyarakat Banda dan Kombut yang berdomisili di wilayah perbatasan Indonesia dan Papua Nugini dan persepsi mereka terhadap bahasa Indonesia, daerah (bahasa Walsa dan Muyu), dan asing (bahasa Negara Papua Nugini) yang berkaitan dengan kebijakan pembinaan bahasa Indonesia dan daerah. Untuk mencapai tujuan itu, model penelitian ini adalah penelitian kuantitatif dengan metode deskriptif. Penelitian ini tergolong penelitian lapangan dengan jenis data primer dan sekunder. Sampel terdiri atas 108 masyarakat tutur Kampung Banda dan 110 Kampung Kombut. Data diolah dengan analisis tabulasi sederhana dan skala skala Likert dengan mengacu pada rumus skor rata-rata. Hasil penelitian menunjukkan bahwa persepsi masyarakat Banda adalah sangat positif terhadap bahasa Indonesia, positif terhadap bahasa Walsa, dan tidak positif terhadap bahasa Negara Papua Nugini. Persepsi masyarakat Kombut adalah positif terhadap bahasa Indonesia, cukup positif terhadap bahasa Muyu, dan cukup positif terhadap bahasa Negara Papua Nugini. Kedua kelompok masyarakat tersebut berpersepsi demikian terhadap bahasa Indonesia dan bahasa daerah masing-masing karena mereka setia, bangga, dan sadar adanya norma bahasa Indonesia, Walsa, dan Muyu. Persepsi
\end{abstract}


masyarakat Banda adalah tidak positif dan masyarakat Kombut cukup positif terhadap bahasa Negara Papua Nugini karena mereka tidak menggunakan bahasa Negara itu sebagai media komunikasi sehari-hari.

Kata kunci: bahasa Indonesia, persepsi masyarakat, wilayah perbatasan, bahasa asing

\section{PENDAHULUAN}

Sumarsono (2012) menyatakan bahwa bahasa merupakan alat komunikasi dominan bagi manusia untuk berkomunikasi antara dua manusia atau lebih. Berdasarkan wilayah penggunaannya, bahasa dibedakan menjadi bahasa nasional, daerah, dan asing. Berdasarkan keadaan penggunaannya, bahasa dibedakan menjadi tiga, yaitu pemertahanan bahasa, pergeseran bahasa, dan kepunahan bahasa. Sementara itu, bahasa berfungsi untuk memenuhi kebutuhan manusia dan dalam kehidupan manusia sebagai makhluk sosial, bahasa berfungsi untuk 1) menggambarkan (represent), 2) mempertukarkan (exchange), dan 3) merangkai (organize) pengalaman manusia. Ketiga fungsi ini disebut metafungsi bahasa oleh Halliday \& Matthiessen (Saragih, 2006).

Seperti diketahui, kebijakan bahasa nasional secara proporsional telah menetapkan fungsi dan peran bahasa nasional (negara), yakni bahasa Indonesia, bahasa daerah, dan bahasa asing. Kesenjangan, sikap, dan perlakuan yang tidak seimbang telah terjadi terhadap ketiga bahasa itu. Walaupun demikian, ketiganya memiliki hakikat masing-masing. Itu sebabnya, pada tanggal 18 Agustus 1945, satu hari setelah proklamasi kemerdekaan, bahasa Indonesia secara legal konstitusional telah dikukuhkan sebagai bahasa negara. Seperti yang tercantum dalam UUD 1945, Bab XV, Pasal 36, bahasa negara adalah bahasa Indonesia. Dasar hukum itu memberikan landasan yang kuat dan resmi bagi pemakaian bahasa Indonesia, bukan saja sebagai bahasa nasional, melainkan juga sebagai bahasa resmi kenegaraan. Selanjutnya, Halim (1984) dalam Muslihah (2015) mengemukakan empat fungsi bahasa Indonesia sebagai bahasa nasional, yaitu 1) lambang kebanggaan kebangsaan, 2) lambang identitas nasional, 3) alat pemersatu berbagai suku bangsa, dan 4) alat perhubungan antardaerah dan antarbudaya. Bahasa Indonesia berkedudukan sebagai bahasa negara berfungsi sebagai 1) bahasa resmi kenegaraan, 2) bahasa pengantar dalam dunia pendidikan, 3) alat perhubungan di tingkat nasional untuk kepentingan pembangunan dan pemerintahan, dan 4) alat pengembangan kebudayaan, ilmu pengetahuan, dan teknologi. Sekarang pun konsep bahasa Indonesia sebagai bahasa persatuan masih tetap dipertahankan dan selalu menjadi simbol dari kejayaan yang pernah dicapai bahasa Indonesia. Sementara itu, dalam kapasitas fungsinya sebagai sarana komunikasi masyarakat, secara kuantitatif bahasa Indonesia pun masih berada pada poisisi sebagai major language (Jalal, 2001).

Setiawan (2016) menyatakan bahwa bahasa daerah merupakan salah satu bukti adanya suatu peradaban masyarakat dahulu yang dalam konteks ini dapat berbentuk lisan atau tulisan. Oleh karena itu, bahasa daerah merupakan sistem ilmu pengetahuan yang didalamnya terdapat nilai yang dimiliki oleh masyarakat yang mempengaruhi perilaku masyarakat itu sendiri. Jika bahasa daerah bergeser, tidak mustahil mengakibatkan pergeseran nilai-nilai yang dimiliki oleh masyarakat, baik perubahan terhadap pandangan hidup, perilaku sosial, maupun hal lain yang sebenarnya merupakan ciri khas budaya masyarakat tersebut. Sesuai dengan keberadaannya di Indonesia, Ethnologue: Language of The World (2005) dalam Tondo (2016) menyatakan bahwa di Indonesia terdapat 737 bahasa yang masih hidup atau masih digunakan oleh penuturnya. Bahasa itu tidak sekedar alat komunikasi dan interaksi saja, tetapi merupakan suatu peninggalan budaya yang harus dijaga dan dipelihara keberadaan dan penggunaanya 
dalam komunikasi sehari-hari.

Miranti, dkk. (2015) menjelaskan bahwa sebutan bahasa asing dalam bidang pengajaran bahasa berbeda dengan bahasa kedua. Bahasa asing adalah bahasa yang yang tidak digunakan sebagai alat komunikasi di negara tertentu di mana bahasa tersebut diajarkan, sedangkan bahasa kedua adalah bahasa yang bukan bahasa utama namun menjadi salah satu bahasa yang digunakan secara umum di suatu negara. Muradi (2015) menyatakan bahwa kebijakan nasional mengenai bahasa asing memberikan arahan bahwa tujuan pengajaran bahasa asing adalah menumbuhkan keterampilan siswa berbahasa asing, sehingga dengan kemampuan itu dapat 1) berkomunikasi dengan bahasa asing tersebut, 2) mengenal dan memahami bangsa dan kebudayan asing tersebut, dan 3) mempelajari ilmu dan kebudayaan asing melalui buku yang ditulis dalam bahasa asing itu dalam rangka studinya.

Sementara itu, ungkapan daerah perbatasan dalam terminologi yang digunakan oleh pemerintah daerah Provinsi Kalimantan Timur adalah daerah yang terletak di sepanjang perbatasan antara negara Republik Indonesia dan negara Malaysia (Mubyarto, 1991 dalam Siburian, 2014). Berpedoman pada terminologi itu, daerah atau wilayah perbatasan di sini mengacu pada daerah yang terletak di sepanjang perbatasan antara negara Republik Indonesia dan negara Papua Nugini. Sehubungan dengan hal itu, pembicaraan wilayah perbatasan tidak dapat dipisahkan dari kesan terisolir, terbatas, dan jauh dari perhatian pemerintah. Kesan seperti itu tidak dapat disalahkan karena demikian adanya pada seluruh wilayah perbatasan Indonesia (Abdullah \& Sari, 2016). Walaupun demikian, wilayah Negara Kesatuan Republik Indonesia (NKRI) yang berbatasan dengan negara-negara lain, misalnya dengan Malaysia, Singapura, Brunei Darusalam, Filipina, Timor Leste, dan Papua New Guine tidak menyurutkan para pemerhati kewilayahan untuk mencermati kondisi di kawasan itu, baik kondisi infrastruktur maupun masyarakatnya.
Setelah hasil kajian wilayah perbatasan dicermati, ternyata kajian kebahasaan pun tidak luput dari pemerhati kewilayahan karena bahasa diasumsikan sebagai aspek penting dalam interaksi manusia. Hal itu cukup beralasan karena dengan bahasa (bahasa lisan, tulisan, atau isyarat) seseorang akan melakukan suatu komunikasi dan kontak sosial dengan orang lain. Bahasa juga dipandang sebagai cermin kepribadian seseorang karena bahasa diterjemahkan sebagai refleksi rasa, pikiran, dan tingkah laku. Akan tetapi, seorang yang pandai dan penuh dengan ide-ide cemerlang harus terhenti hanya karena dia tidak bisa menyampaikan ide atau mengungkapkan kepribadiannya dalam bahasa. Oleh karena itu, bahasa sangat berperan untuk memediakan semua unsur-unsur kepribadian seseorang dalam interaksi masyarakat untuk diketahui atau dievaluasi orang lain.

Jika dicermati wilayah perbatasan di Indonesia, sebagian wilayahnya berbatasan dengan dengan Negara Papua Nugini (Papua New Guinea), seperti halnya Kampung Banda dan Kombut. Masyarakat kedua kampung tersebut kerap berinteraksi dengan sebagian masyarakat negara tetangga (Papua Nugini). Interaksi masyarakat di kedua wilayah perbatasan itu dimungkinkan akan terjadi karena mereka beretnik atau beridentitas bahasa etnik yang sama. Kondisi seperti itu dapat dibenarkan sehingga tidak menutup kemungkinan akan tercipta suatu masyarakat yang dwibahasawan atau anak-anak yang dwibahasa atau bisa jadi multibahasawan atau aneka bahasa. Menurut Aslinda \& Syafyahya (2007), dwibahasawan adalah kemampuan mempergunakan dua bahasa/ bilingualitas dan kebiasaan memakai dua bahasa/bilingualism. Kedwibahasaan itu berkenaan dengan penggunaan dua bahasa atau dua kode bahasa (Chaer \& Agustina, 2010). Fenomena kedwibahasaan memampukan sekelompok masyarakat menuturkan lebih dari satu bahasa.

Penuturan bahasa secara bergantian oleh sekelompok masyarakat tentu berkaitan dengan adanya kontak yang saling berinteraksi. 
Pergerakan manusia yang kian dinamis dimungkinkan akan terjadi sehingga kontak interaksi semakin ekstensif atau intensif dan proses saling mempengaruhi atau berkompetisi akan terjadi. Salah satu fenomena kontak yang menonjol adalah kontak bahasa. Kontak bahasa juga akan dapat menimbulkan fenomena yang berjenjang, yaitu mulai dari peminjaman kata, perubahan sistem morfosintaksis, alih bahasa (language shift) atau sampai kehilangan suatu bahasa (language loss) (MyersScoton, 2002). Kontak bahasa bisa terjadi pada kondisi dimana penutur bahasa mempelajari bahasa lain sebagai bahasa keduanya setelah menguasai bahasa ibunya. Kontak bahasa juga bisa terjadi apabila ada dua bahasa yang digunakan dalam satu komunitas bahasa. Oleh karena itu, tulisan ini untuk mendeskripsikan kondisi ketiga bahasa tersebut dari segi persepsi masyarakat Banda dan Kombut. Dengan demikian, masalah penelitian ini adalah bagaimanakah kondisi karakteristik responden masyarakat Banda dan Kombut serta persepsi mereka terhadap bahasa Indonesia, daerah, dan asing? Tujuan penelitian ini adalah mendeskripsikan karakteristik responden masyarakat Banda dan Kombut dan persepsi mereka terhadap bahasa Indonesia, daerah, dan asing. Manfaatnya diklasifikasikan menjadi dua, yaitu manfaat teoritis dan praktis. Manfaat teoritisnya adalah untuk memberi sumbangan bagi perkembangan teori dan pengetahuan dalam bidang sosiolinguistik pada masyarakat tutur perbatasan. Manfaat praktis adalah untuk meningkatkan kemampuan dan penggunaan bahasa Indonesia dan daerah serta meminimalkan keproduktifan penggunaan bahasa tetangga (asing).

Sehubungan dengan fungsi bahasa sebagai alat komunikasi yang menunjukkan bahwa masyarakat pada masa sekarang tidak hanya mengenal atau menguasai penggunaan satu bahasa saja, tetapi mereka telah mau dan mampu menguasai dua bahasa atau lebih. Penelitian ini menggunakan teori sosiolinguistik karena penelitian ini dikaitkan dengan fenomena kebahasaan dan sifat masyarakat yang berbedabeda di wilayah perbatasan. Seperti diketahui bahwa sosiolinguistik merupakan gabungan antara kata sosiologi dan linguistik, yaitu dua bidang ilmu empiris yang berkaitan erat. Sebagai objek dalam sosiolinguistik, bahasa tidak dilihat atau didekati sebagai bahasa sebagaimana dilakukan dalam linguistik umum, melainkan dilihat atau didekati sebagai sarana interaksi atau komunikasi di dalam masyarakat manusia. Jadi, teori ini memandang bahasa sebagai suatu institusi sosial, baik individu maupun kelompok masyarakat yang melakukan interaksi sosial.

Aslinda \& Syafyahya (2007) menyatakan sosiolinguistik sebagai bidang ilmu antardisiplin yang mempelajari bahasa di dalam masyarakat. Menurut Holmes (2008), sosiolinguistik adalah studi hubungan bahasa dan masyarakat. Sosiolinguistik menurut Chaer \& Agustina (2010) adalah bidang ilmu antardisiplin yang mempelajari bahasa dalam kaitannya dengan penggunaan bahasa itu di dalam masyarakat. Berkaitan dengan hal itu juga, Sumarsono (2011) mendefinisikan sosiolinguistik sebagai kajian keseluruhan masalah yang berhubungan dengan organisasi sosial perilaku bahasa, tidak hanya mencakup pemakaian bahasa saja, melainkan juga sikap bahasa, perilaku terhadap bahasa, dan pemakai bahasa. Sosiolinguistik adalah ilmu yang membahas hubungan bahasa dan masyarakat dengan tujuan agar bahasa itu berfungsi dalam berkomunikasi (Wardhaugh, 2010). Pendapat tersebut mengindikasikan bahwa antara bahasa dan masyarakat memiliki hubungan yang sangat erat. Bahasa sebagai produk sosial dengan berbagai kaitan agar dapat digunakan secara maksimal oleh manusia dalam berkomunikasi dan berinteraksi satu sama lain. Sebagai objek dalam sosiolinguistik, bahasa tidak dilihat atau didekati sebagai bahasa sebagaimana dilakukan oleh linguistik umum, melainkan dilihat atau didekati sebagai sarana interaksi atau komunikasi di dalam masyarakat manusia. Setiap kegiatan kemasyarakatan manusia, mulai dari upacara pemberian nama pada bayi yang baru lahir sampai upacara 
pemakaman jenazah tentu tidak akan terlepas dari penggunaan bahasa. Oleh karena itu, rumusan mengenai sosiolinguistik yang diberikan para pakar tidak akan terlepas dari persoalan hubungan bahasa dengan kegiatan-kegiatan atau aspek-aspek kemasyarakatan. Dengan kata lain, fungsi dasar bahasa adalah alat komunikasi manusia dalam berinteraksi, baik secara lisan maupun tertulis. Bahasa tidak dapat ditinggalkan ketika fungsi ini dikaitkan dengan kehidupan masyarakat sehari-hari yang memiliki nilai-nilai dan status. Ia menjadi bagian tidak terpisahkan dari kehidupan manusia, baik sebaga anggota suku maupun bangsa.

Berkaitan dengan teori sosiolinguistik, digunakan juga teori sikap, sikap bahasa, dan persepsi. Osgood \& Tannenbaum dalam Sobur (2011) mengatakan bahwa sikap dapat diungkapkan melalui bahasa dan sampai batasbatas tertentu tanpa kata-kata, namun konsep sikap akan sangat miskin jika diterapkan pada spesies yang tidak dapat berbicara. Jadi, sikap sangat berkaitan dengan manusia. Sikap atau cara pandang bahasa merupakan peristiwa kejiwaan yang tidak dapat diamati secara langsung, tetapi dapat diamati melalui perilaku berbahasa atau perilaku tutur. Menurut Pateda (1987) dalam Riyanti (2017), sikap bahasa dapat dilihat dari dua segi, yaitu sikap positif dan sikap negatif.

Sikap positif terhadap bahasa adalah sikap antusiasme terhadap penggunaan bahasanya. Garvin \& Mathiot dalam Chaer \& Agustina (2010), menyebutkan ciri-ciri sikap positif terhadap bahasa yang meliputi 1) kesetiaan bahasa (language loyality) yang mendorong masyarakat suatu bahasa mempertahankan bahasanya dan apabila perlu mencegah adanya pengaruh bahasa lain, 2) kebanggaan bahasa (language pride) yang mendorong orang mengembangkan bahasanya dan menggunakannya sebagai lambang identitas dan kesatuan masyarakat, dan 3) kesadaran adanya norma bahasa (awareness of the norm) yang mendorong orang menggunakan bahasanya dengan cermat dan santun; dan merupakan faktor yang sangat besar pengaruhnya terhadap perbuatan, yaitu kegiatan menggunakan bahasa (language use).

Sikap negatif terhadap bahasa akan menyebabkan orang acuh tak acuh terhadap pembinaan dan pelestarian bahasa. Mereka menjadi tidak bangga lagi memakai bahasa sendiri sebagai penanda jati diri. Bahkan, mereka merasa malu memakai bahasa itu (Suandi, 2014). Dalam keadaan demikian, orang mudah beralih atau berpindah bahasa pada bahasa yang lebih bergengsi dan lebih menjamin untuk memperoleh kesempatan di sektor modern dan semacamnya. Apabila ketiga ciri sikap positif terhadap bahasa tersebut sudah menghilang atau melemah dari diri seseorang atau dari diri sekelompok orang anggota masyarakat tutur, itu berarti bahwa sikap negatif terhadap suatu bahasa telah melanda diri seseorang atau sekelompok orang tersebut. Garvin \& Mathiot dalam Chaer \& Agustina (2010) mengemukakan ciri-ciri sikap negatif terhadap bahasa, yaitu 1) seseorang atau sekelompok anggota masyarakat bahasa tidak ada lagi gairah atau dorongan untuk mempertahankan kemandirian bahasanya maka hal itu merupakan suatu petunjuk bahwa kesetiaan bahasanya mulai lemah yang tidak mustahil jika nantinya menjadi hilang sama sekali, 2) seseorang atau sekelompok orang sebagai anggota suatu masyarakat tidak mempunyai rasa bangga terhadap bahasanya dan meng alihkan kebanggaannya kepada bahasa lain yang bukan miliknya, dan 3) seseorang atau sekelompok orang sebagai anggota suatu masyarakat sampai pada ketidaksadaran akan adanya norma bahasa.

Persepsi manusia tentu berbeda untuk mempersepsikan suatu objek. Menurut Sarwono (2003), perbedaan persepsi disebabkan oleh perhatian, set, kebutuhan, sistem nilai, ciri kepribadian, dan gangguan jiwa. Faktor yang berperan dalam persepsi adalah objek yang dipersepsi, alat indera, syaraf dan pusat susunan syaraf, serta perhatian (Walgito, 2001). Jadi, persepsi merupakan sesuatu yang aktif karena menafsirkan dan memaknai pengalaman yang di dalamnya bukan hanya 
stimulus yang memegang peranan melainkan juga faktor individu sebagai orang yang mempersepsi (perseptor). Dengan demikian, maksud persepsi masyarakat Banda dan Kombot dalam penelitian ini adalah kesan yang diungkapkan mereka terhadap bahasa Indonesia, daerah, dan asing.

Sehubungan dengan teori tersebut, kondisi wilayah perbatasan Indonesia dengan negara tetangga sudah dikaji para pemerhati kewilayahan dari berbagai aspek. Kajian Desa Badau sebagai salah satu wilayah perbatasan di Provinsi Kalimantan Barat dengan Serawak (Malaysia) difokuskan pada isu-isu dinamika dan eksistensi tradisi lokal dalam kerangka globalisasi. Adanya ruang interaksi bagi dunia luar dengan kemudahan akses keluar masuk ke negara lain (Serawak, Malaysia) mengakibatkan pola interaksi, informasi dan komunikasi etnis Iban menjadi berkembang (Prasojo, 2016). Menurut Abdullah \& Sari (2016), masyarakat Badau di wilayah perbatasan di Provinsi Kalimantan Barat memiliki tiga identitas, yaitu identitas sebagai masyarakat perbatasan (politik), identitas sebagai bagian dari masyarakat Iban (kultural), dan identitas sebagai bagian dari masyarakat global (ekonomi).

Berbeda dengan kajian tersebut, kajian wilayah perbatasan dari perspektif kebahasaan telah dilakukan oleh para linguis. Sulistyaningtyas (2008) menyatakan bahwa bahasa yang digunakan masyarakat perbatasan Batam untuk sehari-hari dalam pergaulan antaretnis adalah bahasa Melayu, sedangkan untuk pergaulan dalam kelompok etnis digunakan bahasa daerah masing-masing (Melayu, Bugis, Jawa, Bugis, dll.).

Kajian kebahasaan di wilayah perbatasan Kalimantan Utara yang sebelumnya bagian Provinsi Kalimantan Timur dengan Malaysia telah dilakukan oleh Aritonang (2013). Dari hasil penelitian itu terungkap bahwa sebagian masyarakat tutur Sebatik, Kecamatan Sebatik, Kabupaten Nunukan, Provinsi Kalimantan Utara telah mahir berbahasa Indonesia. Sebagian di antara mereka lebih sering menggunakan bahasa
Indonesia daripada bahasa ibu (bahasa lokal) ketika membicarakan politik, ekonomi, pendidikan, sosial-budaya, dan orang yang baru dikenal. Sementara itu, masyarakat perbatasan Provinsi Nusa Tenggara Timur, khususnya di Desa Silawan, Kecamatan Tasifeto Timur, Kabupaten Belu, Provinsi Nusa Tenggara Timur bersikap cukup positif terhadap bahasa Indonesia, bahasa daerah, maupun bahasa asing (Winarti, 2016). Sehubungan dengan itu, tujuan penelitian adalah untuk mendeskripsikan karakteristik masyarakat Banda dan Kombut serta persepsi masyarakat Banda dan Kombut terhadap bahasa Indonesia, daerah, dan asing.

\section{METODE}

Model penelitian ini adalah penelitian kuantitatif dengan metode deskriptif. Metode deskriftif dilakukan karena peneliti ingin menjawab persoalan-persoalan tentang gejala-gejala yang ada atau berlaku pada masa sekarang (Susetyo, 2010). Penelitian ini termasuk penelitian lapangan karena peneliti terjun langsung ke lokasi penelitian untuk mendapatkan data sesuai dengan masalah penelitian.

Populasi penelitian ini masyarakat Kampung Banda dan Kombut yang berdomisili di wilayah perbatasan Indonesia dan Papua. Pengambilan sampel dilakukan dengan cara proportional stratified random sampling, yaitu metode pemilihan sampel dengan cara membagi populasi ke dalam kelompok-kelompok yang homogen yang disebut strata dan kemudian sampel diambil secara acak dari setiap strata secara proporsional. Maksud strata di sini berkaitan dengan kelompok masyarakat. Dengan demikian, sampel yang digunakan adalah 108 orang masyarakat Kampung Banda dan 110 orang Kombut. Untuk mendapatkan data yang valid dan representatif, informan dipilih dengan ketentuan 1) masyarakat asli yang berdomisili di Kampung Banda dan Kombut, 2) kelompok usia < 25 tahun, 25-50 tahun, dan > 51 tahun, dan 3) memiliki waktu yang cukup dan mampu membaca dan menulis.

Jenis data berupa data primer dan sekunder. Data primer diperoleh dengan menggunakan 
metode survei dengan menyebarkan kuesioner, sedangkan data sekunder diperoleh dari catatan-catatan, buku, makalah, laporan, arsip, monografi, wawancara, dan lain-lain yang berkaitan dengan permasalahan penelitian. Angket yang didistribusikan berkaitan dengan persepsi terhadap bahasa Indonesia, daerah, dan asing. Responden tinggal memilih jawaban sesuai dengan variasi jawaban yang telah disediakan. Skala pengukurannya menggunakan skala Likert dengan metode The Method of Summated Ratting. Skala ini relevan digunakan karena pilihan jawaban responden berskala ordinal. Rentang skor yang diterapkan adalah rentang skor $1-5$ sehingga kategori jawaban 1) sangat setuju diberi skor 5 (lima), 2) setuju diberi skor 4 (empat), 3) ragu-ragu diberi skor 3 (tiga), 4) tidak setuju diberi skor 2 (dua), dan 5) sangat tidak setuju diberi skor 1 (satu). Item pertanyaan dalam kuesioner berkaitan dengan tiga hal, yaitu 1) ciri responden dengan 13 item pertanyaan, 2) persepsi terhadap bahasa Indonesia dengan 18 item pertanyaan, 3) persepsi terhadap bahasa daerah dengan 21 item pertanyaan; dan 4) persepsi terhadap bahasa asing dengan 20 item pertanyaan.

Lokasi penelitian adalah Kampung Banda, Distrik Arso Timur, Kabupaten Keerom, Provinsi Papua dan Kampung Kombut, Distrik Kombut, Kabupaten Boven Digoul, Provinsi Papua. Kedua kampung tersebut berbatasan langsung dengan Negara Papua. Waktu pengumpulan data di Kampung Banda adalah tahun 2012 dan Kombut tahun 2013.

\section{HASIL DAN PEMBAHASAN \\ Karakteristik Responden}

Deskripsi karakteristik responden masyarakat Banda dan Kombut mencakup 1) jenis kelamin, 2) usia, 3) status perkawinan, 4) pasangan apakah berasal dari daerah/suku yang sama, 5) pendidikan tertinggi, 6) jumlah bawahan (anak buah) dalam bekerja, 7) tinggal di daerah yang berbahasa yang sama dengan bahasa ibu, 8) bahasa pertama, 9) bahasa pertama pasangan (suami/istri) jika telah berumah tangga, 10) bahasa pertama orang tua perempuan, 11) bahasa pertama orang tua laki-laki, 12) bahasa yang paling dikuasai selain bahasa pertama/ bahasa ibu, dan 13) sering bepergian keluar daerah yang berbahasa lain (lihat Tabel 1 ). Untuk mengetahui karakteristik responden dan persepsi masyarakat terhadap bahasa Indonesia, daerah (bahasa Walsa dan Muyu), dan asing (bahasa Negara Papua Nugini) di wilayah perbatasan, dilakukan analisa tabulasi sederhana dengan uji statistik deskriptif tabulasi sederhana atau analisa tabulasi sederhana (Durianto dalam Riyanto dan Ati Harmoni, 2016) dengan acuan rumus berikut.

$P=\frac{f i}{\sum f i} \times 100 \%$ (1) Rumus statistik

deskriptif tabulasi sederhana

Keterangan:

$\mathrm{P}=$ Persentase responden yang memilih kategori tertentu

$f \mathrm{i}=$ Jumlah responden yang memilih kategori tertentu

$\sum \mathrm{i}=$ Jumlah responden

Tabel 1 menunjukkan bahwa jumlah masyarakat Banda dengan jenis kelamin lakilaki $56(51,9 \%)$ dan perempuan $52(48,1 \%)$. Jumlah masyarakat Kombut dengan jenis kelamin laki-laki adalah $61(55,5 \%)$ dan perempuan 49 $(44,4 \%)$. Jumlah masyarakat Banda dengan kelompok usia $<25$ tahun adalah $33(30,6 \%)$, 25-50 tahun adalah $39(36,1 \%)$, dan usia $>51$ tahun adalah $36(33,3 \%)$. Jumlah masyarakat Kombut dengan kelompok usia $<25$ tahun adalah $26(23,6 \%) ; 25-50$ tahun adalah $63(57,3 \%)$; dan usia $>51$ tahun adalah $21(19,15 \%)$. Jumlah masyarakat Banda tidak ada yang tidak menjawab pertanyaan status perkawinan, menikah $66(61,15 \%)$, dan belum menikah 42 (38,9\%). Jumlah masyarakat Kombut yang menjawab pertanyaan status perkawinan adalah $1(0,9 \%)$, menikah $82(74,55 \%)$, dan belum menikah 27 (24,5\%). Jumlah masyarakat Banda yang tidak menjawab berpasangan dengan sukunya sendiri adalah $31(28,7 \%)$, ya 69 $(63,9 \%)$, dan tidak 8 (7,4\%). Jumlah masya- 
Tabel 1 Karakteritik Masyarakat Banda dan Kombut dalam F dan \%

\begin{tabular}{|c|c|c|c|c|c|c|c|}
\hline \multirow{3}{*}{ No. } & \multirow{3}{*}{\multicolumn{2}{|c|}{ Karakteristik Responden }} & & \multicolumn{4}{|c|}{ Responden } \\
\hline & & & & \multicolumn{2}{|c|}{ Banda } & \multicolumn{2}{|c|}{ Kombut } \\
\hline & & & & $\mathrm{F}$ & $\%$ & $\mathrm{~F}$ & $\%$ \\
\hline \multirow{3}{*}{1} & \multirow{3}{*}{ Jenis kelamin } & Laki-laki & & 56 & 51,9 & 61 & 55,5 \\
\hline & & Perempuan & & 52 & 48,1 & 49 & 44,5 \\
\hline & & & Total & 108 & 100 & 110 & 100 \\
\hline \multirow{4}{*}{2} & \multirow{4}{*}{ Kelompok usia } & $<25$ tahun & & 33 & 30,6 & 26 & 23,6 \\
\hline & & $25--50$ tahun & & 39 & 36,1 & 63 & 57,3 \\
\hline & & $>51$ tahun & & 36 & 33,3 & 21 & 19,1 \\
\hline & & & Total & 108 & 100 & 110 & 100 \\
\hline \multirow{4}{*}{3} & \multirow{4}{*}{$\begin{array}{l}\text { Status } \\
\text { perkawinan }\end{array}$} & Tidak menjawab & & 0 & 0 & 1 & 0,9 \\
\hline & & Nikah & & 66 & 61,1 & 82 & 74,5 \\
\hline & & Belum nikah & & 42 & 38,9 & 27 & 24,5 \\
\hline & & & Total & 108 & 100 & 110 & 100 \\
\hline \multirow{4}{*}{4} & \multirow{4}{*}{$\begin{array}{l}\text { Berpasangan } \\
\text { dengan suku } \\
\text { yang sama }\end{array}$} & Tidak menjawab & & 31 & 28,7 & 1 & 0,9 \\
\hline & & & & 69 & 63,9 & 84 & 76,4 \\
\hline & & Tidak & & 8 & 7,4 & 25 & 22,7 \\
\hline & & & Total & 108 & 100 & 110 & 100 \\
\hline \multirow{5}{*}{5} & \multirow{5}{*}{$\begin{array}{l}\text { Pendidikan } \\
\text { tertinggi }\end{array}$} & Tidak menjawab & & 7 & 6,5 & 0 & 0 \\
\hline & & Pendidikan & & 61 & 56,5 & 98 & 89,1 \\
\hline & & Pendidikan menengah & & 34 & 31,5 & 11 & 10 \\
\hline & & Pendidikan tinggi & & 6 & 5,6 & 1 & 0,9 \\
\hline & & & Total & 108 & 100 & 110 & 100 \\
\hline \multirow{5}{*}{6} & & Tidak menjawab & & 49 & 45,4 & 6 & 5,5 \\
\hline & & $<5$ orang & & 46 & 42,6 & 102 & 92,7 \\
\hline & Bawahan & $5--10$ orang & & 6 & 5,6 & 2 & 1,8 \\
\hline & & $>20$ orang & & 7 & 6,5 & - & \\
\hline & & & Total & 108 & 100 & 110 & 100 \\
\hline & & Tidak menjawab & & 5 & 4,6 & - & \\
\hline 7 & Tingal di daerah & & & 95 & 88 & 110 & 100 \\
\hline ( & berbahasa ibu & Tidak & & 8 & 7,4 & - & \\
\hline & & & Total & 108 & 100 & 110 & 100 \\
\hline & & Bahasa Walsa & & 108 & 100 & 0 & 0 \\
\hline 8 & Rahocanortam & Bahasa Muyu & & 0 & 0 & 77 & 70 \\
\hline 0 & Dandas perlama & Bahasa Indonesia & & 0 & 0 & 33 & 30 \\
\hline & & & Total & 108 & 100 & 110 & 100 \\
\hline & & Tidak menjawab & & 0 & 0 & 1 & 0,9 \\
\hline & & Bahasa Walsa & & 108 & 100 & 0 & 0 \\
\hline 9 & Banasa pertama & Bahasa Muyu & & 0 & 0 & 77 & 70 \\
\hline & & Bahasa Indonesia & & 0 & 0 & 32 & 29,1 \\
\hline & & & Total & 108 & 100 & 110 & 100 \\
\hline & & Bahasa Walsa & & 108 & 100 & 0 & 0 \\
\hline & & Bahasa Muyu & & 0 & 0 & 99 & 90 \\
\hline 10 & Bahasa orang tua & Bahasa Indonesia & & 0 & 0 & 10 & 9,1 \\
\hline & & Bahasa Asing & & 0 & 0 & 1 & 0,9 \\
\hline & & & Total & 108 & 100 & 110 & 100 \\
\hline & & Bahasa Walsa & & 108 & 100 & 0 & 0 \\
\hline & & Bahasa Muyu & & 0 & 0 & 99 & 90 \\
\hline 11 & Bahasa orang tua & Bahasa Indonesia & & 0 & 0 & 10 & 9,1 \\
\hline & & Bahasa asing & & 0 & 0 & 1 & 0,9 \\
\hline & & & Total & 108 & 100 & 110 & 100 \\
\hline & Bahasa daerah & Tidak menjawab & & 0 & 0 & 26 & 23,6 \\
\hline 12 & lain yang & Bahasa Melayu Papua & & 108 & 100 & 84 & 76,4 \\
\hline & & & Total & 108 & 100 & 110 & 100 \\
\hline & & Tidak menjawab & & 16 & 14,8 & 12 & 10,9 \\
\hline & Bepergian ke luar & $<3$ kali seminggu & & 85 & 78,7 & 55 & 50 \\
\hline 13 & daerah yang & 3--10 kali setiap tahun & & 3 & 2,8 & 34 & 30,9 \\
\hline & berbahasa lain & $>10$ kali setiap tahun & & 4 & 3,7 & 9 & 8,2 \\
\hline & & & Total & 108 & 100 & 110 & 100 \\
\hline
\end{tabular}

Sumber: Diolah dari data primer, 2015 
rakat Kombut yang tidak menjawab berpasangan dengan sukunya sendiri adalah 1 $(0,9 \%)$, ya $84(76,4 \%)$, dan tidak $25(22,7 \%)$. Jumlah masyarakat Banda yang tidak menjawab status pendidikan adalah $7(6,5 \%)$, berpendidikan dasar $61(56,5 \%)$, berpendidikan menengah $34(31,5 \%)$, dan berpendidikan tinggi $6(5,6 \%)$. Jumlah masyarakat Kombut berpendidikan dasar adalah $98(89,1 \%)$, berpendidikan menengah $11(10 \%)$, dan berpendidikan tinggi $1(0,9 \%)$. Jumlah masyarakat Banda yang tidak menjawab bawahan bekerja adalah $7(6,5 \%)$, $<5$ orang $46(42,6 \%), 5-10$ orang $6(5,6 \%)$, dan $>20$ Orang $7(6,5 \%)$. Jumlah masyarakat Kombut yang tidak menjawab bawahan bekerja adalah $6(5,5 \%),<5$ orang $102(92,7 \%) ; 5-10$ orang $2(1,8 \%)$, dan $>20$ Orang tidak ada. Jumlah masyarakat Banda yang menjawab tingal di daerah berbahasa ibu adalah $5(4,6 \%)$, ya $95(88 \%)$, dan tidak $8(7,4 \%)$. Jumlah masyarakat Kombut yang menjawab tinggal di daerah berbahasa ibu dengan jawaban ya adalah 110 $(100 \%)$. Jumlah masyarakat Banda yang bahasa pertamanya bahasa Walsa adalah 108 (100\%). Jumlah masyarakat Kombut yang bahasa pertamanya bahasa Muyu adalah 77 (70\%) dan Indonesia 33 (30\%). Jumlah masyarakat Banda dengan bahasa Walsa sebagai bahasa pertama pasangan adalah 108 (100\%). Jumlah masyarakat Kombut dengan bahasa Muyu sebagai bahasa pertama pasangan adalah 77 $(70 \%)$ dan bahasa Indonesia $32(29,1 \%)$. Jumlah masyarakat Banda dengan bahasa Walsa sebagai bahasa orang tua perempuannya adalah $108(100 \%)$. Jumlah masyarakat Kombut dengan bahasa Muyu sebagai bahasa orang tua perempuannya adalah 99 (90\%) dan bahasa Indonesia $10(9,1 \%)$, dan bahasa asing 1 $(0,9 \%)$. Jumlah masyarakat Banda dengan bahasa Walsa sebagai bahasa orang tua lakilaki adalah 108 (100\%). Jumlah masyarakat Kombut dengan bahasa Muyu sebagai bahasa orang tua laki-laki adalah 99 (90\%), bahasa Indonesia $10(9,1 \%)$, dan bahasa asing 1 $(0,9 \%)$. Jumlah masyarakat Banda dengan bahasa Melayu Papua sebagai bahasa daerah lain yang dikuasai adalah 108 (100\%). Masyarakat Kombut tidak menjawab bahasa daerah lain yang dikuasai adalah $26(23,6 \%)$ dan bahasa Melayu Papua 84 (76,4\%). Jumlah masyarakat Banda yang tidak menjawab bepergian ke luar daerah yang berbahasa lain adalah 16 (14,8\%), $<3$ kali seminggu $85(78,7 \%), 3-10$ kali setiap tahun $3(2,8 \%)$, dan $>10$ kali setiap tahun 4 $(3,7 \%)$. Masyarakat Kombut yang tidak menjawab bepergian ke luar daerah yang berbahasa lain adalah $12(10,9 \%),<3$ kali seminggu $55(50 \%), 3-10$ kali setiap tahun 34 $(30,9 \%)$, dan $>10$ kali setiap tahun $9(8,2 \%)$.

\section{Persepsi Masyarakat Banda dan Kombut Terhadap Bahasa Indonesia, Daerah, dan Asing}

Persepsi masyarakat Banda dan Kombut terhadap bahasa Indonesia, daerah, dan asing apakah sangat tidak positif, tidak positif, cukup positif, positif, atau sangat positif ditentukan berdasarkan perhitungan total skor (lihat Tabel 2-Tabel 8). Perhitungannya tentu mengacu pada rumus yang dikemukakan Durianto dalam Riyanto \& Ati Harmoni (2016), yaitu sebagai berikut.

$x=\frac{\sum f i . w i}{\sum f i}$

(2) Rumus skor rata-rata

Keterangan:

$\mathrm{x}=$ Rata-rata berbobot; $f i=$ Frekuensi; $\Sigma f i=$ Bobot

Setiap jawaban responden dari item pertanyaan/pernyataan diberi bobot dengan cara menghitung skor, yaitu menjumlahkah seluruh hasil dikalikan nilai masing-masing bobotnya dibagi dengan jumlah total frekuensi. Setelah itu, digunakan rentang skala penilaian untuk menentukan posisi tanggapan responden dengan menggunakan nilai skor setiap variabel. Bobot alternatif jawaban yang terbentuk dari teknik skala peringkat terdiri dari kisaran $0-5$ yang menggambarkan posisi sangat negatif ke posisi positif. Selanjutnya, dihitung rentang skala dengan rumus berikut. 
$R s=\frac{R(\text { bobot })}{M} \ldots \ldots \ldots$ (3) Rumus rentang skala

Keterangan:

$\mathrm{R}$ (bobot) = Bobot terbesar (maksimal) -bobot terkecil (minimal)

$M=$ Jumlah kategori bobot

Rentang skala Likert yang digunakan dalam penelitian ini adalah $1-5$ sehingga rentang skala penilaian yang didapat melalui rumus tersebut adalah 0,80 dari perhitungan Rs $=\frac{5}{1}$. Hasil perhitungan itu diterapkan dalam skala Likert untuk menunjukkan posisi rentang skala dan interpretasinya, yaitu sebagai berikut.

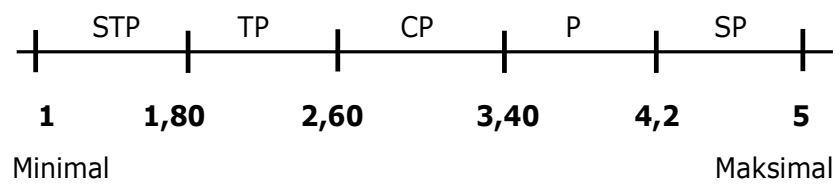

Garis Kontinum 1 Posisi dan Interpretasi Rentang Skala Likert

Keterangan:

$\mathrm{STP}=$ Sangat tidak positif; TP = Tidak positif;

$\mathrm{CP}=$ Cukup positif; $\mathrm{P}=$ Positif;

$\mathrm{SP}=$ Sangat positif

\section{Persepsi Masyarakat Banda terhadap Bahasa Indonesia}

Jumlah item pertanyaan untuk variabel persepsi masyarakat Banda terhadap bahasa Indonesia adalah 17 item pertanyaan sehingga total skor persepsi masyarakat Banda terhadap bahasa Indonesia dapat dilihat pada Tabel 2.

Total skor persepsi masyarakat Banda terhadap bahasa Indonesia pada Tabel 2 adalah 7897. Pengkategoriannya didasarkan pada rentang skor ideal, yaitu (a) jumlah skor maksimal diperoleh dari 5 (skor tertinggi) dikalikan jumlah item pertanyaan dikalikan jumlah responden ( $5 \times 17 \times 108=9180)$, (b) jumlah skor minimal diperoleh dari 1 (skor terendah) dikalikan jumlah item pertanyaan dikalikan jumlah responden $(1 \times 17 \times 108=1836)$, dan (c) rentang skor $=$ skor maksimal dikurangi skor minimal dibagi 5. Berdasarkan ketiga tahapan tersebut, rentang skor untuk persepsi masya- rakat Banda terhadap bahasa Indonesia dapat diidentifikasi dari hasil perhitungan skor maksimal dikurangi skor minimal dibagi 5 atau 91801836:5=1468,8. Dengan demikian, persepsi masyarakat Banda terhadap bahasa Indonesia dapat dilihat pada Garis Kontinum 2.

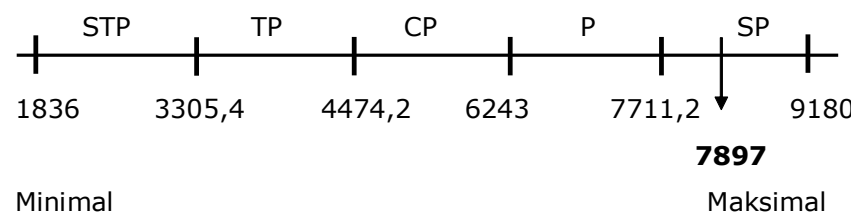

Garis Kontinum 2 Rentang Skor Persepsi Masyarakat Banda terhadap Bahasa Indonesia

Jika dicermati Tabel 2, total skor persepsi masyarakat Banda terhadap bahasa Indonesia berjumlah $\mathbf{7 8 9 7}$ dan tergolong berkategori sangat positif karena terletak di antara rentang skor 7711,2-9180 (lihat Garis Kontinium 2). Hal ini menunjukkan bahwa persepsi masyarakat Banda terhadap bahasa Indonesia sangat positif.

\section{Persepsi Masyarakat Kombut terhadap Bahasa Indonesia}

Jumlah item pertanyaan untuk variabel persepsi masyarakat Kombut terhadap bahasa Indonesia adalah 17 item pertanyaan sehingga total skor persepsi masyarakat Kombut terhadap bahasa Indonesia dapat dilihat pada Tabel 3.

Total skor persepsi masyarakat Kombut terhadap bahasa Indonesia pada Tabel 3 adalah 7147. Pengkategoriannya didasarkan pada rentang skor ideal, yaitu: (a) jumlah skor maksimal diperoleh dari 5 (skor tertinggi) dikalikan jumlah item pertanyaan dikalikan jumlah responden $(5 \times 17 \times 110=9350)$, (b) jumlah skor minimal diperoleh dari 1 (skor terendah) dikalikan jumlah item pertanyaan dikalikan jumlah responden $(1 \times 17 \times 110=1870)$, dan (c) rentang skor $=$ skor maksimal dikurangi skor minimal dibagi 5 atau 9350-1870:5=1496. Dengan demikian, persepsi masyarakat Kombut terhadap bahasa Indonesia adalah positif karena nilai total skor 7147 dan nilai itu terletak di antara skor 63587854 seperti digambarkan pada Garis Kontinum 3. 
Tabel 2 Total Skor Persepsi Masyarakat Banda terhadap Bahasa Indonesia

\begin{tabular}{|c|c|c|c|c|c|c|c|c|}
\hline \multirow{2}{*}{ No. } & \multirow{2}{*}{ Item Pertanyaan (IP) } & \multicolumn{6}{|c|}{ Bobot (wi) } & \multirow{2}{*}{$\begin{array}{l}\text { Skor } \\
\text { wi.fi }\end{array}$} \\
\hline & & 0 & 1 & 2 & 3 & 4 & 5 & \\
\hline 1 & $\begin{array}{l}\text { Setiap orang semestinya } \\
\text { bangga apabila bertelepon/ber- } \\
\text { sms dalam bahasa Indonesia. }\end{array}$ & - & - & 4 & 4 & 36 & 64 & \\
\hline 2 & $\begin{array}{l}\text { Bahasa Indonesia dapat } \\
\text { digunakan untuk menyerap } \\
\text { informasi dan IPTEK. }\end{array}$ & 2 & 4 & 7 & 6 & 35 & 54 & \\
\hline 3 & $\begin{array}{l}\text { Bahasa Indonesia adalah } \\
\text { bahasa yang komunikatif. }\end{array}$ & 5 & - & - & 7 & 37 & 59 & \\
\hline 4 & $\begin{array}{l}\text { Bahasa Indonesia memudahkan } \\
\text { saya mencari pekerjaan. }\end{array}$ & 1 & - & 1 & 1 & 26 & 79 & \\
\hline 5 & $\begin{array}{l}\text { Banyak manfaat yang diperoleh } \\
\text { dengan mempelajari bahasa } \\
\text { Indonesia. }\end{array}$ & 2 & - & - & 1 & 36 & 69 & \\
\hline 6 & $\begin{array}{l}\text { Bahasa Indonesia memudahkan } \\
\text { saya dalam menambah } \\
\text { informasi dan pengetahuan. }\end{array}$ & 1 & - & 1 & 3 & 29 & 74 & \\
\hline 7 & $\begin{array}{l}\text { Bahasa Indonesia mempercepat } \\
\text { upaya pencerdasan bangsa. }\end{array}$ & 1 & 1 & - & 2 & 26 & 78 & \\
\hline 8 & $\begin{array}{l}\text { Bahasa Indonesia bermanfaat } \\
\text { dalam memperluas pergaulan. }\end{array}$ & 1 & - & 1 & 3 & 38 & 65 & \\
\hline \multirow{2}{*}{ No. } & \multirow{2}{*}{ Item Pertanyaan (IP) } & \multicolumn{6}{|c|}{ Bobot (wi) } & Skor \\
\hline & & 0 & 1 & 2 & 3 & 4 & 5 & wi.fi \\
\hline 9 & $\begin{array}{l}\text { Orang yang akan belajar atau } \\
\text { bekerja di Indonesia harus } \\
\text { mampu berbahasa Indonesia. }\end{array}$ & 1 & 1 & & 3 & 32 & 71 & \\
\hline 10 & $\begin{array}{l}\text { Bahasa Indonesia harus } \\
\text { dijadikan syarat pengangkatan } \\
\text { pejabat. }\end{array}$ & 2 & 2 & 1 & 9 & 39 & 55 & \\
\hline 11 & $\begin{array}{l}\text { Semua orang Indonesia harus } \\
\text { bangga berbahasa Indonesia. }\end{array}$ & 1 & 1 & - & 2 & 19 & 85 & \\
\hline 12 & $\begin{array}{l}\text { Setiap orang Indonesia harus } \\
\text { mengupayakan agar anaknya } \\
\text { mampu berbahasa Indonesia. }\end{array}$ & 1 & - & - & 3 & 17 & 87 & \\
\hline 13 & $\begin{array}{l}\text { Bahasa Indonesia harus lebih } \\
\text { diutamakan daripada bahasa } \\
\text { lain. }\end{array}$ & 2 & - & 1 & 6 & 30 & 69 & \\
\hline 14 & $\begin{array}{l}\text { Bahasa Indonesia harus } \\
\text { menjadi bahasa internasional. }\end{array}$ & 2 & 5 & 3 & 7 & 32 & 59 & \\
\hline 15 & $\begin{array}{l}\text { Saya sering mengikuti berita di } \\
\text { radio/televisi. }\end{array}$ & 2 & 11 & 19 & 17 & 41 & 18 & \\
\hline 16 & $\begin{array}{l}\text { Saya sering memperhatikan } \\
\text { penggunaan bahasa di } \\
\text { radio/televisi. }\end{array}$ & 3 & 3 & 11 & 19 & 52 & 20 & \\
\hline \multirow[t]{3}{*}{17} & $\begin{array}{l}\text { Saya sering mengalami } \\
\text { kesulitan ketika memperhatikan } \\
\text { penggunaan bahasa di } \\
\text { radio/televisi. }\end{array}$ & 3 & 3 & 24 & 20 & 39 & 19 & \\
\hline & Total fi & 30 & 31 & 73 & 113 & 564 & 1025 & \\
\hline & Skor wi.fi & 0 & 31 & 146 & 339 & 2256 & 5125 & 7897 \\
\hline
\end{tabular}

Sumber: Diolah dari data primer, 2016

Keterangan Bobot:

0 = Tidak ada jawaban, $1=$ Sangat tidak setuju,

3 = Ragu-ragu,

$4=$ Setuju, dan

2 = Tidak setuju,

5 = Sangat setuju 
Tabel 3 Persepsi Masyarakat Kombut terhadap Bahasa Indonesia

\begin{tabular}{|c|c|c|c|c|c|c|c|c|}
\hline \multirow{2}{*}{ IP } & \multirow{2}{*}{ Pertanyaan } & \multicolumn{6}{|c|}{ Bobot (wi) } & \multirow{2}{*}{$\begin{array}{l}\text { Skor } \\
\text { wi.fi }\end{array}$} \\
\hline & & 0 & 1 & 2 & 3 & 4 & 5 & \\
\hline 1 & $\begin{array}{l}\text { Setiap orang semestinya bangga } \\
\text { apabila bertelepon/ber-sms dalam } \\
\text { bahasa Indonesia. }\end{array}$ & 1 & 1 & 3 & 4 & 98 & 3 & \\
\hline 2 & $\begin{array}{l}\text { Bahasa Indonesia adalah bahasa yang } \\
\text { komunikatif. }\end{array}$ & 1 & - & - & 2 & 17 & 90 & \\
\hline 3 & $\begin{array}{l}\text { Bahasa Indonesia memudahkan saya } \\
\text { mencari pekerjaan. }\end{array}$ & 1 & - & - & 4 & 55 & 50 & \\
\hline 4 & $\begin{array}{l}\text { Banyak manfaat yang diperoleh dengan } \\
\text { mempelajari bahasa Indonesia. }\end{array}$ & 1 & - & 33 & 29 & 35 & 11 & \\
\hline 5 & $\begin{array}{l}\text { Bahasa Indonesia memudahkan saya } \\
\text { dalam menambah informasi dan } \\
\text { pengetahuan. }\end{array}$ & 1 & - & - & 5 & 84 & 20 & \\
\hline 6 & $\begin{array}{l}\text { Bahasa Indonesia mempercepat upaya } \\
\text { pencerdasan bangsa. }\end{array}$ & 1 & - & 1 & 3 & 69 & 36 & \\
\hline 7 & $\begin{array}{l}\text { Bahasa Indonesia bermanfaat dalam } \\
\text { memperluas pergaulan. }\end{array}$ & 1 & - & - & 3 & 52 & 54 & \\
\hline 8 & $\begin{array}{l}\text { Orang yang akan belajar atau bekerja } \\
\text { di Indonesia harus mampu berbahasa } \\
\text { Indonesia. }\end{array}$ & 1 & - & - & 3 & 78 & 28 & \\
\hline 9 & $\begin{array}{l}\text { Bahasa Indonesia harus dijadikan } \\
\text { syarat pengangkatan pejabat. }\end{array}$ & 1 & - & - & 4 & 61 & 44 & \\
\hline 10 & $\begin{array}{l}\text { Semua orang Indonesia harus bangga } \\
\text { berbahasa Indonesia. }\end{array}$ & 1 & - & - & 5 & 40 & 64 & \\
\hline 11 & $\begin{array}{l}\text { Setiap orang Indonesia harus } \\
\text { mengupayakan agar anaknya mampu } \\
\text { berbahasa Indonesia. }\end{array}$ & 1 & - & - & 5 & 37 & 67 & \\
\hline 12 & $\begin{array}{l}\text { Bahasa Indonesia harus lebih } \\
\text { diutamakan daripada bahasa lain. }\end{array}$ & 1 & - & - & 16 & 76 & 17 & \\
\hline 13 & $\begin{array}{l}\text { Bahasa Indonesia harus menjadi bahasa } \\
\text { internasional. }\end{array}$ & 1 & 1 & - & 17 & 73 & 18 & \\
\hline 14 & $\begin{array}{l}\text { Saya sering mengikuti berita di } \\
\text { radio/televisi. }\end{array}$ & 1 & - & 6 & 48 & 52 & 3 & \\
\hline 15 & $\begin{array}{l}\text { Saya sering memperhatikan } \\
\text { penggunaan bahasa di radio/televisi. }\end{array}$ & 1 & - & 8 & 76 & 23 & 2 & \\
\hline 16 & $\begin{array}{l}\text { Saya sering mengalami kesulitan ketika } \\
\text { memperhatikan penggunaan bahasa di } \\
\text { radio/televisi. }\end{array}$ & - & 3 & 73 & 20 & 13 & 1 & \\
\hline 17 & $\begin{array}{l}\text { Bahasa Indonesia makin lama dapat } \\
\text { menggantikan bahasa daerah. }\end{array}$ & 1 & 17 & 61 & 20 & 10 & 1 & \\
\hline & Total fi & 16 & 22 & 148 & 264 & 873 & 509 & \\
\hline
\end{tabular}

Sumber: Diolah dari data primer, 2016

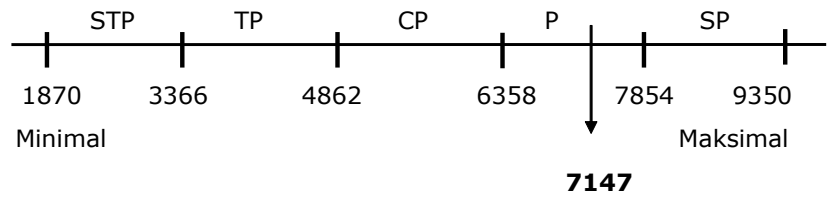

Garis Kontinum 3 Rentang Skor Persepsi Masyarakat Kombut terhadap Bahasa Indonesia

\section{Persepsi Masyarakat Banda terhadap Bahasa Daerah}

Jumlah item pertanyaan untuk variabel persepsi masyarakat Banda terhadap bahasa daerah adalah 20 item pertanyaan sehingga total skor persepsi masyarakat Banda terhadap bahasa daerah dapat dilihat pada Tabel 4 . 
Tabel 4 Persepsi Masyarakat Banda terhadap Bahasa Daerah

\begin{tabular}{|c|c|c|c|c|c|c|c|c|}
\hline \multirow{2}{*}{ No. } & \multirow{2}{*}{ Item Pertanyaan } & \multicolumn{6}{|c|}{ Bobot (wi) } & \multirow{2}{*}{$\begin{array}{l}\text { Skor } \\
\text { wi.fi }\end{array}$} \\
\hline & & 0 & 1 & 2 & 3 & 4 & 5 & \\
\hline 1 & $\begin{array}{l}\text { Bahasa ibu saya lebih baik } \\
\text { daripada bahasa asing. }\end{array}$ & 1 & 4 & 10 & 8 & 32 & 53 & \\
\hline 2 & $\begin{array}{l}\text { Bahasa ibu saya lebih baik } \\
\text { daripada bahasa Indonesia. }\end{array}$ & 1 & 9 & 12 & 18 & 39 & 29 & \\
\hline 3 & $\begin{array}{l}\text { Berita berbahasa daerah lebih } \\
\text { menarik daripada berita } \\
\text { berbahasa Indonesia. }\end{array}$ & 1 & 6 & 10 & 12 & 43 & 36 & \\
\hline 4 & $\begin{array}{l}\text { Bahasa ibu saya lebih baik } \\
\text { daripada bahasa daerah yang } \\
\text { lain. }\end{array}$ & 2 & 2 & 6 & 10 & 39 & 49 & \\
\hline 5 & $\begin{array}{l}\text { Saya bangga jika bahasa saya } \\
\text { dipakai di daerah lain. }\end{array}$ & 1 & 2 & 6 & 1 & 42 & 56 & \\
\hline 6 & $\begin{array}{l}\text { Bahasa daerah penting dipelajari, } \\
\text { bahkan lebih penting daripada } \\
\text { bahasa asing. }\end{array}$ & 3 & 14 & 14 & 14 & 23 & 40 & \\
\hline 7 & $\begin{array}{l}\text { Setiap orang semestinya bangga } \\
\text { apabila bertelepon/ber-sms dalam } \\
\text { bahasa ibu. }\end{array}$ & 5 & 7 & 17 & 11 & 43 & 25 & \\
\hline 8 & $\begin{array}{l}\text { Bahasa daerah digunakan sebagai } \\
\text { ba-hasa pengantar di sekolah } \\
\text { dasar. }\end{array}$ & 1 & 28 & 38 & 8 & 25 & 8 & \\
\hline 9 & $\begin{array}{l}\text { Bahasa daerah terdengar akrab } \\
\text { dan bersahabat. }\end{array}$ & 3 & 10 & 4 & 7 & 41 & 43 & \\
\hline 10. & $\begin{array}{l}\text { Bahasa daerah adalah bahasa } \\
\text { yang komunikatif. }\end{array}$ & 4 & 8 & 6 & 15 & 43 & 32 & \\
\hline 11 & $\begin{array}{l}\text { Banyak manfaat yang diperoleh } \\
\text { dengan mempelajari bahasa } \\
\text { daerah. }\end{array}$ & 1 & 7 & 9 & 18 & 40 & 33 & \\
\hline 12 & $\begin{array}{l}\text { Bahasa daerah memudahkan saya } \\
\text { dalam menambah informasi dan } \\
\text { pengetahuan. }\end{array}$ & 3 & 14 & 16 & 19 & 28 & 28 & \\
\hline 13 & Bahasa daerah mudah dipelajari & 2 & 3 & 5 & 7 & 36 & 55 & \\
\hline 14 & $\begin{array}{l}\text { Bahasa daerah memudahkan saya } \\
\text { mencari pekerjaan. }\end{array}$ & 1 & 22 & 15 & 25 & 28 & 17 & \\
\hline 15 & $\begin{array}{l}\text { Bahasa daerah bermanfaat dalam } \\
\text { memperluas pergaulan. }\end{array}$ & 4 & 10 & 9 & 14 & 40 & 31 & \\
\hline 16 & $\begin{array}{l}\text { Orang yang akan belajar atau } \\
\text { bekerja di daerah harus mampu } \\
\text { berbahasa daerah. }\end{array}$ & 2 & 12 & 14 & 12 & 40 & 28 & \\
\hline 17 & $\begin{array}{l}\text { Bahasa daerah harus dijadikan } \\
\text { syarat pengangkatan pejabat } \\
\text { daerah. }\end{array}$ & 1 & 21 & 24 & 17 & 23 & 22 & \\
\hline 18 & $\begin{array}{l}\text { Setiap orang harus } \\
\text { mengupayakan agar anaknya } \\
\text { mampu berbahasa daerah. }\end{array}$ & 1 & 15 & 19 & 13 & 38 & 22 & \\
\hline 19 & $\begin{array}{l}\text { Bahasa daerah harus lebih } \\
\text { diutamakan daripada bahasa lain. }\end{array}$ & 3 & 12 & 17 & 12 & 31 & 33 & \\
\hline 20 & $\begin{array}{l}\text { Bahasa daerah memperlambat } \\
\text { upaya pencerdasan bangsa. }\end{array}$ & 2 & 23 & 20 & 12 & 31 & 20 & \\
\hline Total & & 42 & 229 & 271 & 253 & 705 & 660 & \\
\hline Skor & vi.fi & 0 & 229 & 542 & 759 & 2820 & 3300 & 7650 \\
\hline
\end{tabular}

Sumber: Diolah dari data primer, 2016 
Total skor persepsi masyarakat Banda terhadap bahasa daerah pada Tabel 4 adalah 7650. Pengkategoriannya didasarkan pada rentang skor ideal, yaitu (a) jumlah skor maksimal diperoleh dari 5 (skor tertinggi) dikalikan jumlah item pertanyaan dikalikan jumlah responden atau $5 \times 20 \times 108=10,800$, (b) jumlah skor minimal diperoleh dari 1 (skor terendah) dikalikan jumlah item pertanyaan dikalikan jumlah responden ( $1 \times 20 \times 108=2160)$, dan (c) rentang skor $=$ skor maksimal dikurangi skor minimal dibagi 5 atau 10,800-2160:5=1728. Dengan demikian, tingkat pengelompokan persepsi masyarakat Banda terhadap bahasa daerah adalah positif, karena nilai total skor $\mathbf{7 6 5 0}$ dan nilai itu terletak di antara skor 7.344-9072, seperti digambarkan pada garis Kontinum 4.

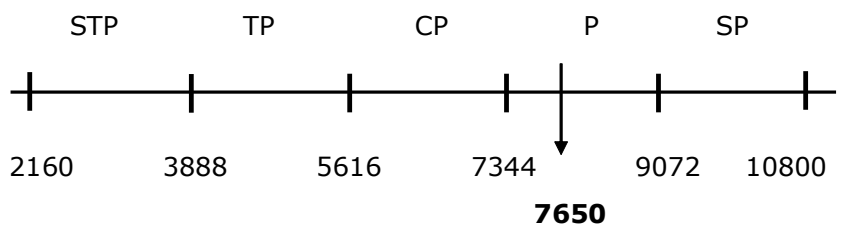

Minimal

Maksimal

Garis Kontinum 4 Rentang Skor Persepsi Masyarakat Banda terhadap Bahasa Daerah

\section{Persepsi Masyarakat Kombut terhadap Bahasa Daerah}

Jumlah item pertanyaan untuk variabel persepsi masyarakat Kombut terhadap bahasa daerah adalah 21 item pertanyaan. Untuk total skor persepsi masyarakat itu terhadap bahasa daerah dapat dilihat pada Tabel 5 .

Total skor persepsi masyarakat Kombut terhadap bahasa daerah pada Tabel 5 adalah 6487. Pengkategoriannya didasarkan pada rentang skor ideal, yaitu: (a) jumlah skor maksimal diperoleh dari 5 (skor tertinggi) dikalikan jumlah item pertanyaan dikalikan jumlah responden $(5 \times 21 \times 110=11550)$, (b) jumlah skor minimal diperoleh dari 1 (skor terendah) dikalikan jumlah item pertanyaan dikalian jumlah responden $(1 \times 21 \times 110=2310)$, dan (c) rentang skor $=$ skor maksimal dikurangi skor minimal dibagi 5 atau $11550-2310: 5=$ 1848. Dengan demikian, persepsi masyarakat
Kombut terhadap bahasa daerah adalah cukup positif karena nilai total skor adalah 6487 dan terletak di antara skor 6006-7854, seperti digambarkan pada Garis Kontinum 5.

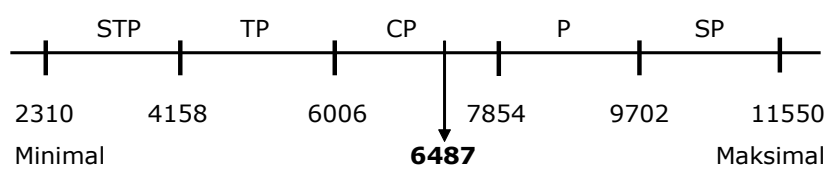

Garis Kontinum 5 Rentang Skor Persepsi Masyarakat Kombut terhadap Bahasa Daerah

\section{Persepsi Masyarakat Banda terhadap Bahasa Asing}

Jumlah item pertanyaan untuk variabel persepsi masyarakat Kombut terhadap bahasa asing adalah 20 item pertanyaan. Berdasarkan hal itu, total skor persepsi masyarakat Kombut terhadap bahasa asing dapat ditentukan berdasarkan ke20 item pertanyaan dimaksud dan dapat dilihat pada Tabel 6.

Total skor persepsi masyarakat Banda terhadap bahasa asing pada Tabel 6 adalah 5364. Pengkategoriannya didasarkan pada rentang skor ideal, yaitu (a) jumlah skor maksimal diperoleh dari 5 (skor tertinggi) dikalikan jumlah item pertanyaan dikalikan jumlah responden ( $5 \times 20 \times 108=10800)$, (b) jumlah skor minimal diperoleh dari 1 (skor terendah) dikalikan jumlah item pertanyaan dikalikan jumlah responden $(1 \times 20 \times 108=2160)$, dan (c) rentang skor $=$ skor maksimal dikurangi skor minimal dibagi 5 atau $10800-2160: 5=\mathbf{1 7 2 8}$. Dengan demikian, persepsi masyarakat Banda terhadap bahasa asing adalah tidak positif karena nilai total skor adalah $\mathbf{6 4 8 7}$ dan terletak di antara skor 3888--5616, seperti digambarkan pada Garis Kontinum 6.

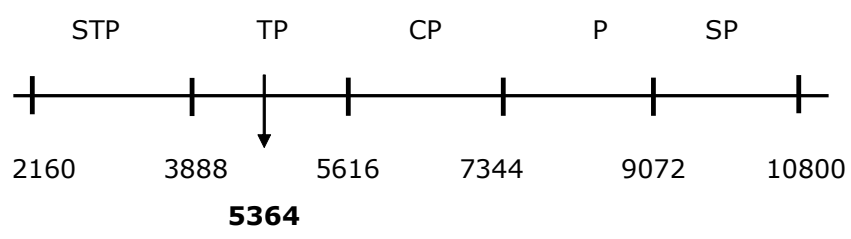

Minimal

Maksimal

Garis Kontinium 6 Rentang Skor Persepsi Masyarakat Banda Terhadap Bahasa Asing 
Tabel 5 Persepsi Masyarakat Tutur Kombut terhadap Bahasa Daerah

\begin{tabular}{|c|c|c|c|c|c|c|c|c|}
\hline \multirow{2}{*}{ IP } & \multirow{2}{*}{ Pertanyaan } & \multicolumn{6}{|c|}{ Bobot (wi) } & \multirow{2}{*}{$\begin{array}{l}\text { Skor } \\
\text { wi.fi }\end{array}$} \\
\hline & & 0 & 1 & 2 & 3 & 4 & 5 & \\
\hline 1 & $\begin{array}{l}\text { Bahasa ibu saya lebih baik daripada } \\
\text { bahasa asing. }\end{array}$ & - & - & 1 & 18 & 60 & 31 & \\
\hline 2 & $\begin{array}{l}\text { Bahasa ibu saya lebih baik daripada } \\
\text { bahasa Indonesia. }\end{array}$ & - & - & 48 & 54 & 6 & 2 & \\
\hline 3 & $\begin{array}{l}\text { Berita berbahasa daerah lebih menarik } \\
\text { daripada berita berbahasa Indonesia. }\end{array}$ & - & - & 73 & 29 & 7 & 1 & \\
\hline 4 & $\begin{array}{l}\text { Bahasa ibu saya lebih baik daripada } \\
\text { bahasa daerah yang lain. }\end{array}$ & 1 & - & - & 58 & 50 & 1 & \\
\hline 5 & $\begin{array}{l}\text { Saya bangga jika bahasa saya dipakai di } \\
\text { daerah lain. }\end{array}$ & - & 12 & 55 & 39 & 4 & - & \\
\hline 6 & $\begin{array}{l}\text { Bahasa daerah penting dipelajari, } \\
\text { bahkan lebih penting daripada bahasa } \\
\text { asing. }\end{array}$ & - & - & - & 1 & 92 & 17 & \\
\hline 7 & $\begin{array}{l}\text { Setiap orang semestinya bangga apabila } \\
\text { bertelepon/ber-sms dalam bahasa ibu. }\end{array}$ & 1 & - & - & 5 & 61 & 43 & \\
\hline 8 & $\begin{array}{l}\text { Bahasa daerah digunakan sebagai } \\
\text { bahasa pengantar di sekolah dasar. }\end{array}$ & - & - & - & 57 & 51 & 2 & \\
\hline 9 & $\begin{array}{l}\text { Bahasa daerah terdengar akrab dan } \\
\text { bersahabat. }\end{array}$ & - & - & - & 7 & 40 & 63 & \\
\hline 10 & $\begin{array}{l}\text { Bahasa daerah adalah bahasa yang } \\
\text { komunikatif. }\end{array}$ & - & - & - & 7 & 48 & 55 & \\
\hline 11 & $\begin{array}{l}\text { Banyak manfaat yang diperoleh dengan } \\
\text { mempelajari bahasa daerah. }\end{array}$ & - & - & - & 7 & 67 & 36 & \\
\hline 12 & $\begin{array}{l}\text { Bahasa daerah memudahkan saya dalam } \\
\text { menambah informasi dan pengetahuan. }\end{array}$ & - & - & 1 & 30 & 74 & 5 & \\
\hline 13 & Bahasa daerah mudah dipelajari & 1 & - & - & 8 & 60 & 41 & \\
\hline 14 & $\begin{array}{l}\text { Bahasa daerah memudahkan saya } \\
\text { mencari pekerjaan. }\end{array}$ & - & 10 & 69 & 19 & 11 & 1 & \\
\hline 15 & $\begin{array}{l}\text { Bahasa daerah bermanfaat dalam } \\
\text { memperluas pergaulan. }\end{array}$ & - & - & 3 & 27 & 77 & 2 & \\
\hline 16 & $\begin{array}{l}\text { Orang yang akan belajar atau bekerja di } \\
\text { daerah harus mampu berbahasa daerah. }\end{array}$ & 1 & 63 & 32 & 6 & 8 & - & \\
\hline 17 & $\begin{array}{l}\text { Bahasa daerah harus dijadikan syarat } \\
\text { pengangkatan pejabat daerah. }\end{array}$ & 1 & 65 & 32 & 9 & 3 & - & \\
\hline 18 & $\begin{array}{l}\text { Setiap orang harus mengupayakan agar } \\
\text { anaknya mampu berbahasa daerah. }\end{array}$ & 1 & - & - & 46 & 54 & 9 & \\
\hline 19 & $\begin{array}{l}\text { Bahasa daerah harus lebih diutamakan } \\
\text { daripada bahasa lain. }\end{array}$ & 1 & 1 & - & 32 & 68 & 8 & \\
\hline 20 & $\begin{array}{l}\text { Bahasa daerah memperlambat upaya } \\
\text { pencerdasan bangsa. }\end{array}$ & 1 & 74 & 25 & 6 & 4 & - & \\
\hline \multirow[t]{3}{*}{21} & $\begin{array}{l}\text { Saya sering memperhatikan penggunaan } \\
\text { bahasa dalam koran (majalah) } \\
\text { berbahasa daerah }\end{array}$ & 1 & 3 & 89 & 16 & 1 & - & \\
\hline & Total fi & 9 & 228 & 306 & 380 & 773 & 283 & \\
\hline & Skor wi.fi & 0 & 228 & 612 & 1140 & 3092 & 1415 & 6487 \\
\hline
\end{tabular}

Sumber: Diolah dari data primer, 2016

\section{Persepsi Masyarakat Kombut terhadap Bahasa Asing}

Jumlah item pertanyaan untuk variabel persepsi masyarakat Kombut terhadap bahasa asing adalah 20 item pertanyaan sehingga total skor persepsi masyarakat Kombut terhadap bahasa asing dapat dilihat pada Tabel 7. 
Tabel 6 Total Skor Persepsi Masyarakat Banda terhadap Bahasa Asing

\begin{tabular}{|c|c|c|c|c|c|c|c|c|}
\hline \multirow{2}{*}{ No. } & \multirow{2}{*}{ Item Pertanyaan } & \multicolumn{6}{|c|}{ Bobot (wi) } & \multirow{2}{*}{$\begin{array}{l}\text { Skor } \\
\text { wi.fi }\end{array}$} \\
\hline & & 0 & 1 & 2 & 3 & 4 & 5 & \\
\hline 1 & $\begin{array}{l}\text { Bahasa asing penting dipelajari, bahkan } \\
\text { lebih penting daripada bahasa daerah. }\end{array}$ & 2 & 25 & 12 & 11 & 29 & 29 & \\
\hline 2 & $\begin{array}{l}\text { Setiap orang semestinya bangga apabila } \\
\text { bertelepon/ber-sms dalam bahasa asing. }\end{array}$ & 2 & 36 & 23 & 26 & 13 & 8 & \\
\hline 3 & $\begin{array}{l}\text { Berita berbahasa asing lebih menarik } \\
\text { daripada berita berbahasa Indonesia. }\end{array}$ & 1 & 41 & 29 & 18 & 10 & 9 & \\
\hline 4 & $\begin{array}{l}\text { Bahasa asing digunakan sebagai bahasa } \\
\text { pengantar di sekolah dasar. }\end{array}$ & 2 & 32 & 29 & 13 & 18 & 14 & \\
\hline 5 & $\begin{array}{l}\text { Bahasa asing adalah bahasa yang } \\
\text { komunikatif. }\end{array}$ & 5 & 30 & 15 & 29 & 14 & 15 & \\
\hline 6 & $\begin{array}{l}\text { Banyak manfaat yang diperoleh dengan } \\
\text { mempelajari bahasa asing. }\end{array}$ & 7 & 26 & 15 & 12 & 35 & 13 & \\
\hline 7 & $\begin{array}{l}\text { Bahasa asing mempercepat usaha } \\
\text { pencerdasan bangsa. }\end{array}$ & 3 & 29 & 18 & 10 & 33 & 15 & \\
\hline 8 & $\begin{array}{l}\text { Bahasa asing memudahkan saya dalam } \\
\text { menambah informasi dan pengetahuan. }\end{array}$ & 1 & 31 & 13 & 11 & 35 & 17 & \\
\hline 9 & Bahasa asing mudah dipelajari. & 2 & 30 & 40 & 21 & 12 & 3 & \\
\hline 10 & $\begin{array}{l}\text { Bahasa asing memudahkan saya mencari } \\
\text { pekerjaan. }\end{array}$ & 3 & 33 & 25 & 18 & 21 & 8 & \\
\hline 11 & $\begin{array}{l}\text { Bahasa asing bermanfaat dalam } \\
\text { memperluas pergaulan. }\end{array}$ & 5 & 31 & 14 & 23 & 26 & 9 & \\
\hline 12 & $\begin{array}{l}\text { Bahasa asing harus dijadikan syarat } \\
\text { pengangkatan pejabat. }\end{array}$ & 2 & 41 & 31 & 15 & 16 & 3 & \\
\hline 13 & $\begin{array}{l}\text { Semua orang Indonesia harus bangga } \\
\text { berbahasa asing. }\end{array}$ & 2 & 39 & 27 & 16 & 17 & 7 & \\
\hline 14 & $\begin{array}{l}\text { Setiap orang Indonesia harus } \\
\text { mengupayakan agar anaknya mampu } \\
\text { berbahasa asing. }\end{array}$ & 1 & 30 & 20 & 15 & 34 & 8 & \\
\hline 15 & $\begin{array}{l}\text { Bahasa asing harus lebih diuta-makan } \\
\text { daripada bahasa lain. }\end{array}$ & 4 & 38 & 34 & 20 & 7 & 5 & \\
\hline 16 & $\begin{array}{l}\text { Orang yang menguasai bahasa asing } \\
\text { tampak lebih cerdas. }\end{array}$ & 2 & 22 & 14 & 12 & 37 & 21 & \\
\hline 17 & $\begin{array}{l}\text { Bahasa asing makin lama dapat } \\
\text { menggeser bahasa Indonesia. }\end{array}$ & 4 & 39 & 39 & 9 & 12 & 5 & \\
\hline 18 & $\begin{array}{l}\text { Bahasa asing lebih kaya kata-kata-nya } \\
\text { dibandingkan dengan bahasa Indonesia. }\end{array}$ & 3 & 38 & 29 & 13 & 15 & 10 & \\
\hline 19 & $\begin{array}{l}\text { Bahasa asing lebih modern dibandingkan } \\
\text { dengan bahasa Indonesia. }\end{array}$ & 1 & 35 & 29 & 18 & 18 & 7 & \\
\hline 20 & $\begin{array}{l}\text { Bahasa asing dapat menambah gengsi } \\
\text { saya }\end{array}$ & 5 & 30 & 27 & 15 & 26 & 5 & \\
\hline Tot & & 57 & 656 & 483 & 325 & 428 & 211 & \\
\hline Sko & wi.fi & 0 & 656 & 966 & 975 & 1712 & 1055 & 536 \\
\hline
\end{tabular}

Sumber: Diolah dari data primer, 2016

Total skor persepsi masyarakat Banda terhadap bahasa asing pada Tabel 7 adalah 5732. Pengkategoriannya didasarkan pada rentang skor ideal, yaitu: (a) jumlah skor maksimal diperoleh dari 5 (skor tertinggi) dikalikan jumlah item pertanyaan dikalikan jumlah responden $(5 \times 20 \times 110=11000)$, (b) jumlah skor minimal diperoleh dari 1 (skor terendah) dikalikan jumlah item pertanyaan dikalikan jumlah responden $(1 \times 20 \times 110=2200)$, dan (c) rentang skor $=$ skor maksimal dikurangi skor minimal dibagi 5 atau $11000-2200: 5=1760$. Dengan demikian, persepsi masyarakat Kombut terhadap bahasa asing adalah cukup positif karena nital total skor adalah $\mathbf{5 7 3 2}$ dan nilai itu terletak di antara nilai 5720-7480, seperti digambarkan pada Garis Kontinum 7. 
Tabel 7 Persepsi Masyarakat Kombut terhadap Bahasa Asing

\begin{tabular}{|c|c|c|c|c|c|c|c|c|}
\hline \multirow{2}{*}{ IP. } & \multirow{2}{*}{ Pertanyaan } & \multicolumn{6}{|c|}{ Bobot (wi) } & \multirow{2}{*}{$\begin{array}{l}\text { Skor } \\
\text { wi.fi }\end{array}$} \\
\hline & & 0 & 1 & 2 & 3 & 4 & 5 & \\
\hline 1 & $\begin{array}{l}\text { Bahasa asing penting dipelajari, } \\
\text { bahkan lebih penting daripada } \\
\text { bahasa daerah. }\end{array}$ & 2 & - & 36 & 68 & 3 & - & \\
\hline 2 & $\begin{array}{l}\text { Setiap orang semestinya bangga } \\
\text { apabila bertelepon/ber-sms dalam } \\
\text { bahasa asing. }\end{array}$ & 2 & - & 91 & 16 & 1 & - & \\
\hline 3 & $\begin{array}{l}\text { Berita berbahasa asing lebih } \\
\text { menarik daripada berita berbahasa } \\
\text { Indonesia. }\end{array}$ & 2 & 2 & 83 & 23 & - & - & \\
\hline 4 & $\begin{array}{l}\text { Bahasa asing digunakan sebagai } \\
\text { bahasa pengantar di sekolah dasar. }\end{array}$ & 2 & 2 & 81 & 22 & 3 & - & \\
\hline 5 & $\begin{array}{l}\text { Bahasa asing adalah bahasa yang } \\
\text { komunikatif. }\end{array}$ & 2 & - & 6 & 92 & 10 & - & \\
\hline 6 & $\begin{array}{l}\text { Banyak manfaat yang diperoleh } \\
\text { dengan mempelajari bahasa asing. }\end{array}$ & 2 & - & 5 & 71 & 32 & - & \\
\hline 7 & $\begin{array}{l}\text { Bahasa asing mempercepat usaha } \\
\text { pencerdasan bangsa. }\end{array}$ & 2 & - & 33 & 60 & 15 & - & \\
\hline 8 & $\begin{array}{l}\text { Bahasa asing memudahkan saya } \\
\text { dalam menambah informasi dan } \\
\text { pengetahuan. }\end{array}$ & 2 & - & 6 & 51 & 49 & 1 & \\
\hline 9 & Bahasa asing mudah dipelajari. & 2 & 1 & 7 & 52 & 45 & 3 & \\
\hline 10 & $\begin{array}{l}\text { Bahasa asing memudahkan saya } \\
\text { mencari pekerjaan. }\end{array}$ & 2 & 13 & 62 & 29 & 4 & - & \\
\hline 11 & $\begin{array}{l}\text { Bahasa asing bermanfaat dalam } \\
\text { memperluas pergaulan. }\end{array}$ & 2 & - & 2 & 47 & 55 & 4 & \\
\hline 12 & $\begin{array}{l}\text { Bahasa asing harus dijadikan } \\
\text { syarat pengangkatan pejabat. }\end{array}$ & 2 & 65 & 31 & 10 & 2 & - & \\
\hline 13 & $\begin{array}{l}\text { Semua orang Indonesia harus } \\
\text { bangga berbahasa asing. }\end{array}$ & 1 & 1 & 72 & 31 & 3 & 2 & \\
\hline 14 & $\begin{array}{l}\text { Setiap orang Indonesia harus } \\
\text { mengupayakan agar anaknya } \\
\text { mampu berbahasa asing. }\end{array}$ & 1 & 1 & 1 & 68 & 37 & 2 & \\
\hline 15 & $\begin{array}{l}\text { Bahasa asing harus lebih } \\
\text { diutamakan daripada bahasa lain. }\end{array}$ & 1 & 4 & 73 & 25 & 6 & 1 & \\
\hline 16 & $\begin{array}{l}\text { Orang yang menguasai bahasa } \\
\text { asing tampak lebih cerdas. }\end{array}$ & 1 & 1 & 35 & 63 & 10 & 1 & \\
\hline 17 & $\begin{array}{l}\text { Bahasa asing makin lama dapat } \\
\text { menggeser bahasa Indonesia. }\end{array}$ & 2 & 19 & 52 & 10 & 22 & 5 & \\
\hline 18 & $\begin{array}{l}\text { Bahasa asing lebih kaya kata- } \\
\text { katanya dibandingkan dengan } \\
\text { bahasa Indonesia. }\end{array}$ & 1 & 12 & 70 & 20 & 5 & 2 & \\
\hline 19 & $\begin{array}{l}\text { Bahasa asing lebih modern } \\
\text { dibandingkan dengan bahasa } \\
\text { Indonesia. }\end{array}$ & 1 & 14 & 65 & 22 & 7 & 1 & \\
\hline 20 & $\begin{array}{l}\text { Bahasa asing dapat menambah } \\
\text { gengsi saya }\end{array}$ & 1 & 4 & 43 & 49 & 13 & - & \\
\hline & Total fi & 33 & 139 & 854 & 829 & 322 & 22 & \\
\hline & Skor wi.fi & 0 & 139 & 1708 & 2487 & 1288 & 110 & 5732 \\
\hline
\end{tabular}

Sumber: Diolah dari data primer, 2016

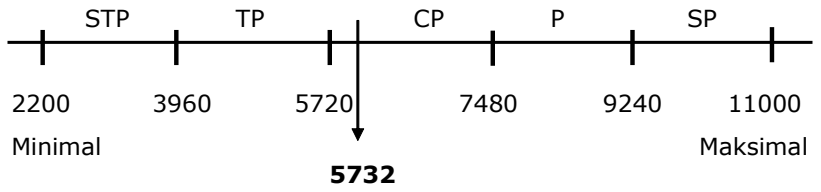

Garis Kontinum 7 Rentang Skor Persepsi Masyarakat Kombut terhadap Bahasa Asing

\section{Pembahasan}

Hasil penelitian menunjukkan bahwa jumlah dan persentase tiga belas karakteristik responden pada Tabel 1, yaitu 1) jenis kelamin, 2) usia, 3) status perkawinan, 4) pasangan apakah berasal dari daerah/suku yang sama, 5) pendidikan 
Tabel 8 Rangkuman Persepsi Masyarakat Tutur Kombut terhadap Bahasa Indonesia, Daerah, dan Asing

\begin{tabular}{cllcccc}
\hline No. $\begin{array}{l}\text { Persepsi } \\
\text { Masyarakat }\end{array}$ & $\begin{array}{l}\text { Terhadap } \\
\text { Jenis Bahasa }\end{array}$ & $\begin{array}{l}\text { Total } \\
\text { Skor }\end{array}$ & $\begin{array}{c}\text { Posisi Total } \\
\text { Skor dalam } \\
\text { Rentang Skala }\end{array}$ & Keterangan & Tabel \\
\hline \multirow{2}{*}{1} & \multirow{2}{*}{ Banda } & Bahasa Indonesia & 7897 & $6243-7711,2$ & Sangat positif & 2 \\
\cline { 3 - 7 } & & Bahasa daerah & 7650 & $7344-9072$ & Positif & 4 \\
\cline { 3 - 7 } & Bahasa asing & 5764 & $3888-5616$ & Tidak positif & 6 \\
\hline \multirow{2}{*}{ 2. Kombut } & Bahasa Indonesia & 7147 & $6358-7854$ & Positif & 3 \\
\cline { 3 - 7 } & Bahasa daerah & 6486 & $6006-7854$ & Cukup positif & 5 \\
\cline { 2 - 6 } & Bahasa asing & 5732 & $5720-7480$ & Cukup positif & 7 \\
\hline
\end{tabular}

tertinggi, 6) jumlah bawahan (anak buah) dalam bekerja, 7) tinggal di daerah yang berbahasa yang sama dengan bahasa ibu, 8) bahasa pertama, 9) bahasa pertama pasangan (suami/ istri) jika telah berumah tangga, 10) bahasa pertama orang tua perempuan, 11) bahasa pertama orang tua laki-laki, 12) bahasa yang paling dikuasai selain bahasa pertama/bahasa ibu, dan 13) sering bepergian keluar daerah yang berbahasa lain baik responden masyarakat Banda dan Kombut berbeda-beda.

Persepsi masyarakat Banda dan Kombut terhadap bahasa Indonesia, daerah, dan asing berbeda-beda. Persepsi masyarakat Banda terhadap bahasa Indonesia adalah sangat positif dan masyarakat Kombut positif. Hal itu dibuktikan oleh jawaban kedua masyarakat tersebut yang mempersepsikan 17 item pernyataan tentang bahasa Indonesia dengan sangat setuju. Persepsi itu pula dipertegas dengan ciri-ciri sikap positif terhadap bahasa, yaitu adanya kesetiaan bahasa, kebanggaan bahasa, dan kesadaran adanya norma bahasa, khususnya terhadap bahasa Indonesia (Garvin \& Mathiot dalam Chaer \& Agustina (2010). Perasaan bangga yang ditimbulkan oleh sikap positif masyarakat Banda dan Kombut terhadap bahasa Indonesia tentu berkaitan erat dengan rasa setia terhadap bahasa Indonesia.

Persepsi masyarakat Banda dan Kombut terhadap bahasa daerah menunjukkan bahwa masyarakat Banda berpersepsi positif terhadap bahasa

Walsa dan masyarakat Kombut berpersepsi cukup positif terhadap bahasa Muyu. Kedua kelompok masyarakat berpersepsi demikian didasarkan bukti, yaitu masyarakat Banda mempersepsikan ke-20 item pernyataan tentang bahasa Walsa dengan setuju dan masyarakat Kombot mempersepsikan 21 item pernyataan tentang bahasa Muyu dengan setuju juga. Berdasarkan hal itu, persepai masyarakat Banda dan Kombut terhadap bahasa daerah masingmasing, baik bahasa Walsa maupun Muyu sama dengan persepsi mereka terhadap bahasa Indonesia, yaitu setia, bangga, dan sadar adanya norma bahasa bahasa Walsa dan Muyu.

Persepsi masyarakat Banda terhadap bahasa asing tidak positif, sedangkan masyarakat Kombut cukup positif. Persepsi seperti itu dibuktikan dengan pilihan jawaban masyarakat Kombut yang sangat tidak setuju dan masyarakat Kombut yang tidak setuju terhadap ke20 item pernyataan tentang persepsi mereka terhadap bahasa asing. Walaupun rentang persepsi kedua kelompok masyarakat tersebut demikian, itu dapat dimaknai bahwa mereka tidak menggunakan bahasa asing (Negara Papua Nugini) sebagai media komunikasi seharihari, yaitu bahasa Tok Pisin (Melanesian Pidgin English), Inggris, dan Hiri Motu.

Tingkat persepsi masyarakat Banda dan Kombut terhadap ketiga bahasa tersebut dipengaruhi oleh kontak dan kebijakan bahasa. Apabila terdapat dua bahasa atau lebih digunakan secara bergantian oleh penutur yang sama, akan terjadi kontak bahasa (Suwito (1983). Oleh karena itu, tingkat persepsi yang telah diidentifikasi tersebut disebabkan peristiwa saling kontak antara bahasa yang satu dengan 
bahasa yang lainnya (language contacts) dalam peristiwa komunikasi. Tingkat persepsi itu sangat terkait juga dengan kebijakan bahasa di Indonesia, yakni kebijakan terhadap bahasa nasional atau bahasa negara (bahasa Indonesia), bahasa daerah (bahasa Walsa dan Muyu), dan bahasa asing/bahasa Negara Papua Nugini, yaitu bahasa Tok Pisin (Melanesian Pidgin English), Inggris, dan Hiri Motu. Moeliono (2011) dengan tegas merumuskan bahwa kebijakan bahasa atau garis haluan bahasa mengandung sinonim dengan istilah politik bahasa. Kebijakan bahasa mengenal bahasa Indonesia, bahasa golongan etnis lain yang ada di nusantara, dan bahasa asing yang terdapat di Indonesia dan digunakan untuk tujuan tertentu. Kebijakan bahasa dinyatakan lebih-lebih menggambarkan pendapat dan sikap masyarakat tentang bahasa yang hidup di dalamnya. Saragih (2011) pun menyatakan bahwa tiga kebijakan bahasa, yaitu terkait dengan kebijakan bahasa di Indonesia dengan cakupan bahasa nasional/negara daerah seperti bahasa Batak, dan asing seperti bahasa Inggris. Esensi kebijakan bahasa nasional adalah mengedepankan dan mengutamakan pemakaian bahasa nasional atau bahasa negara, yaitu bahasa Indonesia. Tujuannya adalah untuk menguatkan bahasa Indonesia sebagai sarana komunikasi dan pemersatu dalam kedaulatan Negara Kesatuan Republik Indonesia. Berkaitan dengan kebijakan bahasa, bahasa daerah merupakan sumber pemerkaya bahasa Indonesia dan berfungsi sebagai alat pemersatu penutur bahasa daerah di daerah dan sarana pengungkapan budaya daerah. Bahasa asing diharapkan dipelajari, termasuk bahasa Walsa dan Muyu. Rosmawaty (2017) menegaskan bahwa tujuan ideal implementasi kebijakan bahasa nasional, yaitu menciptakan warga negara Indonesia yang mengutamakan dan mengedepankan bahasa Indonesia, menghargai bahasa daerah (bahasa ibu atau bahasa pertama), dan menguasai bahasa asing. Jadi, persepsi penguasaan masyarakat Banda dan Kombut yang berdomisili di wilayah perbatasan Negara Kesatuan Republik Indonesia dengan Negara Papua Nugini terhadap bahasa Indonesia, daerah (bahasa Walsa dan Muyu), dan asing (bahasa Tok Pisin, Inggris, dan Hiri Motu) terikat dengan adanya kontak bahasa dan gambaran kebijakan bahasa nasional di Indonesia yang harus dicermati.

\section{KESIMPULAN DAN SARAN \\ Kesimpulan}

Masyarakat Banda berpersepsi sangat positif terhadap bahasa Indonesia, positif terhadap bahasa Walsa, dan tidak positif terhadap bahasa asing. Etnik Kombut berpersepsi positif terhadap bahasa Indonesia, cukup positif terhadap bahasa Muyu, dan cukup positif terhadap bahasa asing. Persepsi masyarakat Banda dan Kombut demikian, baik terhadap bahasa Indonesia maupun bahasa daerah (bahasa Walsa oleh masyarakat Banda dan bahasa Muyu oleh masyarakat Kombut) karena mereka setia, bangga, dan sadar adanya norma bahasa Indonesia, Walsa, dan Muyu. Masyarakat Banda yang berpersepsi tidak positif dan etnik Kombut cukup positif terhadap bahasa asing karena mereka tidak menggunakan bahasa asing (bahasa Negara Papua Nugini) sebagai media komunikasi sehari-hari. Kondisi penutur bahasa di kampung Walsa dan Kombut dapat dijadikan kebijakan pembinaan dan pengembangan bahasa oleh pemerintah daerah di Indonesia.

\section{Saran}

Selain kajian persepsi masyarakat Banda dan Kombut terhadap bahasa Indonesia, daerah, dan asing, khususnya masyarakat yang berdomisili di wilayah perbatasan Indonesia dengan negara tetangga masih perlu ditindaklanjuti. Hal itu sangat bermanfaat untuk mengetahui situasi kebahasaan masyaratat tutur di wilayah itu. 


\section{PUSTAKA ACUAN}

Abdullah, I. \& Sari, I.P. Politik Identitas Masyarakat Perbatasan Indonesia-Malaysia: Kasus Badau di Kapuas Hulu, Kalimantan Barat. Jurnal Kawistara, 4(3),225-330, https:// jurnal.ugm.ac.id/index.php/kawistara/article/view/6378/5036), diakses tanggal 16 Januari 2016.

Aritonang, B. 2013. Kemampuan dan Pandangan Masyarakat Tutur Sebatik terhadap Bahasa Indonesia, Daerah, dan Asing. Yogyakarta: Lokus Tiara Wacana Group.

Aslinda \& Syafyahy. 2007. Pengantar Sosiolinguistik. Bandung: PT. Rafika.

Chaer, A. \& Leonie A. 2010. Sosiolinguistik Perkenalan Awal. Jakarta: PT Rineka Cipta.

Miranti, I., Engliana, \& Fitri S.H. 2015. Penggunaan Media Lagu Anak-Anak dalam Mengembangkan Kemampuan Kosakata Bahasa Inggris Siswa di PAUD. Faktor Jurnal I/miah Kependidikan, 2(2) 167-173, http://journal.Ippmunindra.ac.id/index.php/Faktor/ article/view/382/364, diakses 29 Januari 2016.

Holmes, J. 2008. An Introduction to Sociolinguistics. England: Pearson Education Limited. Jalal, M. 2001. Nasionalisme Bahasa Indonesia dan Kompleksitas Persoalan Sosial dan Politik. Masyarakat, Kebudayaan dan Politik, XIV(1) 81-92, http://www.journal.unair.ac.id/ filerPDF/06-jalal.pdf, diakses 14 Februasi 2016.

Moeliono, A. 2010. Kebijakan Bahasa dan Perencanaan Bahasa di Indonesia: Kendala dan Tantangan. Dalam Perencanaan Bahasa pada Abad Ke-21: Kendala dan Tantangan (Risalah Simposium Internasional Perencanaan Bahasa), Sugiyono dan Yeyen Maryani (Ed.). Jakarta: Badan Pengembangan dan Pembinaan Bahasa, Kementerian Pendidikan dan Kebudayaan.

Muradi, A. 2015. Pembelajaran Menulis Bahasa Arab dalam Perspektif Komunikatif. Jakarta: Prenada Media Group.

Muslihah, N.N. 2015. Menumbuhkan Sikap Positif terhadap Bahasa Indonesia melalui Pemahaman Makna Sumpah Pemuda. Dalam Prosiding Seminar Nasional Bulan Bahasa 2015. Unit Penerbitan FKIP Universitas Bengkulu, pp. 301-314, http://repository.unib.ac.id/11138/, diakses tanggal 23 Februasi 2016.

Myers-Scotton, C. 2002. Contact Linguistics. Oxford: Oxford University Press.

Prasojo, Z.H. 2013. Dinamika Masyarakat Lokal di Perbatasan. Walisongo: Jurnal Penelitian Sosial Keagamaan 21(2),417-436. http://www.journal.walisongo.ac.id/index.php/walisongo/ article/view/252/233, diakses 5 Desember 2016.

Riyanti, W. 2017. Sikap terhadap Bahasa Indonesia Siswa Kelas X SMA Negeri 2 Tulang Bawang Udik, Kabupaten Tulang Bawang Barat Tahun Pelajaran 2016/2017 dan Implikasinya dalam Pembelajaran Bahasa Indonesia di SMA. Skripsi. Bandar Lampung: Fakultas Keguruan dan IImu Pendidikan, Universitas Lampung.

Riyantoro, B. \& Ati H. 2013. Efektivitas Iklan Melalui Jejaring Sosial Sebagai Salah Satu Strategi Pemasaran Keripik Pedas Maicih. Prosiding PESAT 5, E256-E263 http:// www.ejournal.gunadarma.ac.id/index.php/pesat/article/viewFile/923/813, diakses 7 September 2016.

Rosmawaty. 2013. Kebertahanan Bahasa Daerah dalam Konteks Kebijakan Bahasa Nasional Indonesia: Kasus Bahasa Batak. Jurnal Bahasa dan Seni 41(2), 191-202, http:// journal2.um.ac.id/index.php/ibs/article/view/109, diakses 10 September 2017. 
Saragih, A. 2006. Bahasa dalam Konteks Sosial. Medan: PPS Unimed.

Sarwowo, S.W. 2003. Pengantar Psikologi Umum. Jakarta: Bulan Bintang.

Siburian, R. 2002. Entikong: Daerah Tanpa Krisis Ekonomi di Perbatasan Kalimantan BaratSarawak. Jurnal Antropologi Indonesia, 87-93 http://journal.ui.ac.id/index.php/jai/article/ view/3431/2712, diakses tanggal 15 Februasi 2016.

Suandi, I.N. 2014. Sosiolinguistik. Yogyakarta: Graha Ilmu.

Sobur, A. 2011. Psikologi Umum. Bandung: Pustaka Setia.

Sugiyono. 2010, Metode Penelitian Kuantitatif Kualitatif dan R dan D. Bandung: Penerbit CV Alfabeta.

Sulistyaningtyas, T. 2008. Pemantapan Ketahanan Nasional NKRI melalui Pendekatan Kebahasaan: Studi Kasus Masyarakat Perbatasan di Batam. Jurnal Sosioteknologi, 7(13), 334-344, http://journals.itb.ac.id/index.php/-sostek/, diakses 9 Februari 2016.

Sumarsono. 2011. Sosiolinguistik. Yogyakarta: Pustaka Pelajar.

Susetyo. 2010. Tindakan Penelitian Kuantitatif dan Penelitian Kelas. Bengkulu: Universitas Bengkulu.

Suwito. 1983. Pengantar Awal Sosiolinguistik, Teori dan Problema. Surakarta: Kenary Offset

Tondo, H. 2009. Kepunahan Bahasa-Bahasa Daerah: Faktor Penyebab dan Implikasi Etnolinguistis. Jurnal Masyarakat dan Budaya 11(2), 277-296.

Walgito, B. 2001. Pengantar Psikologi Umum. Yogyakarta: Andi.

Wardhaugh, R. 2010. An Introduction to Linguistics. Singapore: Blackwell.

Winarti, S. 2015. Sikap Bahasa Masyarakat di Wilayah Perbatasan NTT: Penelitian Sikap Bahasa pada Desa Silawan, Provinsi Nusa Tenggara Timur. Jurnal Metalingua 13(2), 215-227. http://metalingua.kemdikbud.go.id/jurnal/index.php/metalingua/article/view/8/8, diakses 24 Februari 2016. 